\title{
Review \\ Sleep Disturbance, Sleep Disorders and Co-Morbidities in the Care of the Older Person
}

\author{
Christine E. Mc Carthy ${ }^{1,2}$
}

check for

updates

Citation: Mc Carthy, C.E. Sleep

Disturbance, Sleep Disorders and Co-Morbidities in the Care of the Older Person. Med. Sci. 2021, 9, 31. https://doi.org/10.3390/

medsci9020031

Academic Editor: Grazia D'Onofrio

Received: 25 April 2021

Accepted: 18 May 2021

Published: 21 May 2021

Publisher's Note: MDPI stays neutral with regard to jurisdictional claims in published maps and institutional affiliations.
1 Department of Geriatric Medicine, University Hospital Galway, Galway, Ireland; C.MCCARTHY54@nuigalway.ie

2 HRB-Clinical Research Facility, National University of Ireland, Galway, Co., Galway, Ireland

\begin{abstract}
Sleep complaints can be both common and complex in the older patient. Their consideration is an important aspect of holistic care, and may have an impact on quality of life, mortality, falls and disease risk. Sleep assessment should form part of the comprehensive geriatric assessment. If sleep disturbance is brought to light, consideration of sleep disorders, co-morbidity and medication management should form part of a multifaceted approach. Appreciation of the bi-directional relationship and complex interplay between co-morbidity and sleep in older patients is an important element of patient care. This article provides a brief overview of sleep disturbance and sleep disorders in older patients, in addition to their association with specific co-morbidities including depression, heart failure, respiratory disorders, gastro-oesophageal reflux disease, nocturia, pain, Parkinson's disease, dementia, polypharmacy and falls. A potential systematic multidomain approach to assessment and management is outlined, with an emphasis on non-pharmacological treatment where possible.
\end{abstract}

Keywords: sleep; sleep disorders; older patient; geriatric medicine; comprehensive geriatric; assessment; co-morbidity; co-morbidities

\section{Introduction}

Sleep, which has an important role in human health, is commonly disrupted in those aged $\geq 65$ years [1-4]. This disruption has been previously described as a multifaceted geriatric syndrome [5]. Given that sleep impairment is associated with increased risks of mortality, cardiovascular disease, impaired quality of life (QOL) and falls, it should be a target of holistic patient management, and not considered a normal phenomenon of ageing [6-9]. In this article, the author discusses the potential causes of sleep impairment in older age, in addition to an approach to its assessment and management, with specific sections on sleep disorders and co-morbidities.

\section{What Disturbs Sleep in the Older Patient}

While not a consequence of healthy ageing, older patients are at a higher risk of sleep impairment than their younger counterparts $[10,11]$. Typical changes in sleep architecture and continuity seen in older age include reduction in slow wave sleep (SWS), percentage of rapid eye movement (REM) sleep, total sleep time (TST), sleep efficiency (proportion of time in bed spent asleep) and an increase in sleep onset latency (time to fall asleep) [12]. Older people can also experience phase advance in their internal sleep-wake cycle (circadian rhythm), going to bed and getting up earlier [13]. The reason for this susceptibility is not yet fully determined. It is likely a multifactorial phenomenon, with intrinsic and extrinsic factors exerting influence. (See Table 1).

From a neurological and endocrinal perspective, there are a lot of potential factors that can impair sleep. Neurotoxin deposition, age related blood brain barrier dysfunction and local small vessel disease may cause grey and white matter loss, disrupting sleep spindle and SWS generation. In addition, neurotransmitter dysregulation may directly impair sleep drive, and neurodegeneration in the suprachiasmatic nucleus can impact 
the normal circadian rhythm [14]. Accumulation of lens pigmentation and loss of certain retinal ganglion cells may reduce light transmission and also negatively influence circadian rhythm $[15,16]$. Secretion of certain hormones, such as cortisol and growth hormones that have a circadian rhythm or are secreted during certain sleep phases, may also change with ageing, with a potential direct or indirect effect on sleep [13].

Table 1. Examples of intrinsic and extrinsic factors that may negatively impact sleep in older patients.

\begin{tabular}{cc}
\hline Intrinsic Factors & Extrinsic Factors \\
\hline Changes in the ageing brain & Life events \\
Changes in hormone secretion & Physical activity \\
Changes to the lens and retina & Social engagement \\
Cumulative co-morbidity & Medications \\
\hline
\end{tabular}

Life events, such as bereavement and loss, are more common in older age, and are also associated with sleep problems $[17,18]$. In addition, low levels of physical activity and social engagement in older adults have been associated with sleep impairment [19-21].

The prevalence of primary sleep disorders, such as insomnia, sleep disordered breathing (SDB) and REM sleep are also common in older people [4,22-24]. In addition, increasing chronic conditions in older life and medication numbers are associated with impaired sleep $[21,25,26]$. The relationship in some cases may be bi-directional, with insufficient sleep being both a consequence of and risk factor for disease development [27].

\section{Sleep Disorders and the Older Patient}

\subsection{Insomnia}

Insomnia is common in older age, although reported prevalence varies [28]. Diagnosis requires persistent difficulty with sleep and secondary daytime dysfunction, despite adequate sleep opportunity [29]. The diagnosis is made clinically, through careful history taking and exclusion of other sleep disorders. Where another sleep disorder is suspected, such as sleep disordered breathing (SDB), referral for polysomnography (PSG) should be considered $[27,30]$. Subjective measures, such as sleep diaries and rating and screening scales, may also assist the diagnosis, but it should be noted that many have not been validated in the older population or in patients with cognitive impairment [31-33].

Where possible, non-pharmacologic therapy should be considered as first-line treatment. A recent systematic review of sleep hygiene education (SHE) for treatment of insomnia found that SHE was associated with sleep improvements [34]. Cognitive Behavioural Therapy for Insomnia (CBT-I) was the more effective option in the same systematic review, and appears to significantly improve symptoms in older patients $[35,36]$. In one randomised controlled trial (RCT) of older patients with insomnia, in fact, CBT-I appeared superior to zopiclone for both short and long-term management [37]. One significant barrier to CBT-I, however, is access to therapists [38]. Given this, digital CBT-I (dCBT-I) is an emerging possibility in the older patient cohort [39]. Relaxation and mindfulness techniques also have a role in treatment $[34,36]$. Results vary or are limited for other non-pharmacological approaches [40,41].

Pharmacological management of insomnia in older patients should be undertaken with absolute caution. While statistically significant effects on sleep continuity have been seen with hypnotic use, the magnitude of the effects are small, and associated risks are both significant and clinically relevant [42]. These risks include falls, hip fractures, impairment of cognitive function and higher overall mortality [43-47]. CBT-I should generally be considered as first-line treatment for chronic insomnia in older patients [48]. Abad and Guilleminault recommended that hypnotic medications may be considered as adjunctive therapy initially if insomnia symptoms are severe, impacting activities of daily living (ADL) or QOL [49]. A short course with a plan for discontinuation is recommended, with short-acting drugs preferred and choice of agent dependent on the predominant insomnia symptom. Benzodiazepines are not recommended initially, and should only be 
considered as a second-line option [49]. Consideration of co-morbidities such as depression and their management, in addition to medication review, is also an important element of care. Melatonin may also be helpful, particularly when sleep onset insomnia symptoms predominate, in older patients [50-52].

\subsection{Sleep Disordered Breathing}

SDB is the umbrella term used to describe many disorders of the respiratory pattern occurring periodically during sleep, including obstructive sleep apnoea (OSA) and central sleep apnoea (CSA) [53]. The incidence of SDB increases with age, with a wide variety of prevalence reported in older adults [54]. Patients with OSA frequently stop breathing during sleep due to obstruction of the upper airway, while CSA is characterised by apnoeic events in the absence of respiratory effort [55]. OSA has been associated with obesity, diabetes, hypertension (HTN) and many other co-morbidities, while CSA is more commonly associated with left ventricular failure, opioid use and neurodegenerative disease $[53,56,57]$. It has been suggested that the phenotype of OSA differs between older and younger adults, with worsening of the upper airway anatomy having a more significant role to play in older patients, in addition to a weaker association with obesity $[58,59]$.

The typical presentation of OSA in a younger patient of nocturnal snoring, choking, nocturia and excessive daytime sleepiness does not necessarily occur in the older patient $[60,61]$. Screening tools may be helpful in the geriatric clinic, however, again, there is limited literature in relation to validation of these tools, with the vast majority of studies being conducted with participants of a mean age of $<65$ years [62]. PSG is the gold standard diagnostic tool, however, the use of portable or home-based devices is increasing [53,63]. While the majority of research in these devices was also conducted in patients with a mean age of $<65$ years, they have been studied in geriatric populations, and they do appear to be effective for diagnosis in patients at high risk of the disorder [63-65].

SDB has been associated with stroke, nocturnal hypertension, glaucoma, falls and mortality in the older population [66-72]. A significant association has also been observed between SDB and cognitive impairment [73]. Given this, treatment of SDB should be considered important in older patients [74]. Positive airway pressure therapy (PAP) is the gold standard of care, and there is some evidence to support its use in older populations, where it has been associated with a reduction in falls, improved cognition, improved cardiovascular outcomes, improved outcomes post-stroke and improved QOL [70,75-82]. In addition, age alone does not seem to impact PAP adherence, and reasonable adherence has also been observed in patients with mild to moderate Alzheimer's dementia (AD) [83,84]. Minimisation of sedative medications in addition to optimising the management of other comorbidities are also key areas to consider $[53,54,74]$.

\subsection{Restless Leg Syndrome}

Restless leg syndrome (RLS) is a movement disorder characterised by an urge to move the limbs in response to an uncomfortable sensation [85]. The lower limbs are most commonly affected, with a nocturnal predominance of symptoms [86]. Screening questions such as: "When you try to relax in the evening or sleep at night, do you ever have unpleasant, restless feelings in your legs that can be relieved by walking or movement?" may be helpful, and have been studied in patients with a mean age of $>60$ years [87]. There are several mimics of RLS, including leg cramps, positional discomfort, leg oedema, neuropathy, myalgia and arthritis, and use of a diagnostic criteria should establish the diagnosis, such as the International Restless Legs Syndrome Study Group (IRLSSG) diagnostic criteria [88]. Reported community prevalence ranges between $1.9 \%$ and $15 \%$, generally increasing with age [89]. Dysfunction of the dopaminergic system and iron deficiency are thought to be involved in its pathogenesis [90,91]. RLS is also associated with many other common co-morbidities, including cardiovascular disease, hypertension, diabetes and depression [92-94]. 
Sleep symptoms are common in RLS, with patients reporting an inability to fall or stay asleep [95]. Associations with daytime sleepiness, fatigue and issues with daytime functioning have also been reported [96]. In two large cross-sectional studies, sleep symptoms were reported as the "most troublesome" symptom by more than one-third of participants $[95,97]$. Severity of symptoms in older patients has also been linked to poorer QOL, social and daily functioning and emotional well-being [98].

Evidence based non-pharmacological therapy for RLS is scarce. A recent systematic review found that exercise, counter-strain manipulation, compression devices, repetitive transcranial magnetic stimulation, infrared therapy, acupuncture, vibration pads and yoga were associated with improved outcomes [99]. Studies were deemed not of high quality in this systematic review, however, with few identified, and the majority of participants were $<65$ years old [99]. Consideration of potentially exacerbating medications may be helpful, with some serotonergic antidepressant medications implicated, and bupropion potentially helpful [100]. The evidence, however, is very limited, and medication review should be individualised [100,101].

Obtaining serum ferritin levels in patients with RLS should be considered, as replacement of iron in deficient patients can improve symptoms [102-104]. The American Academy of Neurology recommends considering ferrous fumarate supplementation in combination with vitamin C in patients with RLS and serum ferritin of $<75 \mathrm{mcg} / \mathrm{L}$, and considering IV iron replacement if severe symptoms are present [85]. In the setting of iron deficiency anaemia in the older patients, other specific considerations should be undertaken, including the impact of chronic disease on ferritin level, work up for cause and the tolerance of oral supplementation [105].

Pharmacological options, including dopamine agonists, alpha-2 delta calcium channel ligands and levodopa, should be considered in cases where sleep, QOL or daytime functioning is impaired [85]. Opioids and benzodiazepines may also be helpful, but caution should be undertaken due to their side effect profile, to which older patients are particularly susceptible $[85,106,107]$. In relation to subjective sleep complaints, there is some evidence to support the use of ropinirole, pramipexole, rotigotine, gabapentin enacabril, pregabalin and levodopa [85,108-116]. It should be noted, however, that the mean age was $<60$ years in these studies [108-116]. The author recommends considering the individual patient in the context of potential side effects and medication interactions prior to considering therapeutic options.

\subsection{REM Sleep Behavioural Disorder}

REM sleep behaviour disorder (RBD) is a parasomnia characterised by the lack of paralysis during REM sleep, resulting in patients "acting out their dreams". Unpleasant and vivid dreams are also a common symptom $[117,118]$. It is a disorder of older age, typically diagnosed between the ages of 50-85 years [118]. A recent population-based study of 1977 adults between the ages of 40-80 years estimated the prevalence of RBD at $1.06 \%$ [119].

RBD has been associated with poorer QOL in addition to poorer subjective sleep quality in comparison to healthy controls [120]. Sleep-related injuries to the patient and/or their bed partner may also occur [121,122]. Many patients with RBD are also subsequently diagnosed with a neurodegenerative disorders of synuclein aggregation, such as Parkinson's disease (PD), dementia with Lewy bodies (DLB) and multiple system atrophy (MSA) $[123,124]$. A recent prospective cohort study of 1280 patients with RBD found an overall annual conversion rate to neurodegenerative disease of $6.3 \%$, with $73.5 \%$ conversion over 12 years of follow-up [125]. RBD likely represents a prodromal phase of the disease in these instances, but it is yet to be determined whether the sleep disturbance is entirely secondary to the ongoing neurodegenerative process, or contributes to the disease pathogenesis [126].

RBD's definitive diagnosis requires PSG [29]. The single screening question in older patients-"Have you ever been told, or suspected yourself, that you seem to 'act out 
your dreams' while asleep (for example, punching, flailing your arms in the air, making running movements, etc.)?"- may be useful, in addition to interviewing the bed partner $[118,127,128]$. Differential diagnosis includes OSA, sleep walking, sleep terrors, nocturnal frontal lobe epilepsy, periodic limb movement, arousals associated with confusion, dissociative states and malingering [118].

No established guidelines exist in relation to the management of RBD, and large RCTs have not been undertaken $[118,129]$. The main goal of treatment currently is to prevent sleep-related injuries and dreams patients find disturbing. The decision to start pharmacotherapy should be made on an individual basis, and should not generally be considered unless there is injurious behaviour or significant sleep disruption $[118,130]$. Pharmacologic options include clonazepam and melatonin, but these recommendations are based predominantly on case series, prospective studies and expert opinions $[118,131]$. Recent small RCTs have not determined either medication efficacious, and larger RCT trials are needed [132-134].

Modification of the sleep environment, including removing dangerous items, placing the mattress on the floor and sleeping in separate beds, may help prevent injury in cases with injurious behaviour [135]. Consideration of other potential sleep disorders should also be undertaken. In addition, tricyclic and serotonergic antidepressants and lipophilic beta blockers may exacerbate RBD and should be considered for review in patients, if thought medically appropriate [129].

\section{Common Co-Morbidities and Their Relationship with Sleep}

\subsection{Depression}

Depression in the older population may present differently than in the younger population, and older patients with depression may be more likely to report sleep disturbance [136,137]. A bi-directional relationship likely exists in relation to sleep disturbance and depression, with sleep disturbance representing both a risk for, and symptom of, depression $[138,139]$.

In younger patients with concomitant depression and insomnia, augmenting treatment for depression with CBT-I has been associated with improved depressive and sleep symptoms [140]. CBT-I has also been associated with improved depression and insomnia severity in older adults with both conditions, and should be considered in this group [141]. Medication review and pharmacological therapy should also be considered, when indicated. In patients with depression and insomnia, certain medications for depression may negatively impact sleep. Selective serotonin reuptake inhibitors (SSRIs) and serotonin-norepinephrine reuptake inhibitors (SNRIs), for example, have been associated with increased wakefulness, insomnia and reduced REM sleep time [142]. Sedative antidepressants may be preferable when conditions co-exist, however, the majority of research in this area has been undertaken in younger patients. In middle-aged patients, mirtazapine has been associated with reduced hypnotic co-prescription when compared to SSRIs [143]. Increased total sleep time and reduced sleep onset latency was observed in an open-label study of mirtazapine in six patients aged $<65$ years with depression [144]. Similar effects were seen with trazadone in 10 middle-aged patients with depression [145]. Agomelatine was also associated with improved sleep parameters in a similar study of middle-aged patients, and may be beneficial for older patients with depression and co-morbid insomnia [146,147].

\subsection{Heart Failure}

Patients with heart failure (HF) commonly complain of non-restorative sleep, increased sleep onset latency, night time awakenings and early morning wakening $[148,149]$. Insomnia and SDB are also more prevalent in HF patients than in the general population [150-152]. The relationship between HF and sleep is, again, likely bi-directional. Sleep disturbance is associated with several cardiovascular disease risk factors, and cardiovascular disease, in addition to higher sympathetic activity [153-155]. With this considered, sleep disturbance may lie along the causal pathway for forms of HF, or potentially exacerbate 
the condition. In contrast, nocturnal symptoms of HF, such as orthopnoea and paroxysmal nocturnal dyspnoea, may cause or exacerbate sleep disturbance [156]. The Rotterdam Study found that clinical heart failure, but not cardiac dysfunction alone, predicted a reduction in sleep quality in longitudinal analysis, implicating HF symptoms in sleep disturbance [157]. In addition, nocturia and diuretics in HF patients have been associated with impaired sleep $[158,159]$. Concomitant depression and mood disorders may also have a significant impact [156].

Optimising HF management may positively impact sleep quality, while diagnosis and treatment of underlying sleep disorders should also be considered. There is some evidence, for example, suggesting that angiotensin converting enzyme (ACE) inhibitors may positively impact sleep in heart failure patients $[160,161]$. Beta blockers may also positively impact CSA in HF [162]. In addition, manipulating the timing of diuretic therapy to avoid periods of sleep, with consideration of diuretic half-life, has been recommended $[158,159,163]$.

\subsection{Chronic Respiratory Disorders}

Reduced sleep quality has been associated with chronic respiratory disorders, including chronic obstructive pulmonary disease (COPD) and asthma $[164,165]$. In this setting, a relationship between poor sleep quality and lower oxygen saturations has been observed $[164,166]$. Level of asthma control has also been associated with sleep quality and sleep duration [167-169]. Again, with respiratory disorders and sleep, relationships are likely bidirectional, with nocturnal symptoms of respiratory illnesses likely contributing to arousals, and sleep dysfunction potentially influencing lung function and inflammation [170,171].

Optimal treatment of patients with sleep problems and respiratory disorders is complex. Sleep and stages of sleep can affect breathing through multiple mechanisms, including reduction in skeletal muscle tone and reduced ventilatory response to chemical and mechanical stimulus, potentially leading to inadequate ventilation during sleep in compromised lungs [172]. The possibility of co-morbid SDB, hypoxia and hypercapnia should be considered [173]. One review suggests that referral for overnight pulse oximetry should be considered in patients with low daytime oxygen saturations $(<93 \%)$, and referral for PSG if symptoms are suggestive of SDB in COPD [174]. It should be noted, however, that long-term oxygen therapy in COPD patients with moderate desaturation has not been shown to have an impact on disease outcomes including sleep quality [175].

Management should include optimisation of the underlying respiratory condition. Improved asthma control, for example, has been associated with improved sleep quality [169]. Medical optimisation is, however, complex. Some medications, such as theophylline and corticosteroids, may negatively impact sleep $[176,177]$. These findings, however, have not been consistent, and these medications may improve sleep in patients with respiratory disease [178]. An individual approach in the older population, with cognisance of medication side effects, should be undertaken, while considering the disease guidelines. Hypnotics should be avoided where possible, especially benzodiazepine medications, due to the risk of respiratory depression, while melatonin may be a promising potential treatment option [179-182].

\subsection{Pain and Disorders Associated with Pain}

Chronic pain and insomnia are closely associated, with $50.4 \%$ of chronic insomnia participants in one cross-sectional study reporting chronic pain [25]. The relationship is, again, likely bi-directional, with experimental evidence of pain being associated with night time arousals, and sleep deprivation being associated with increased spontaneous pain incidence $[183,184]$. Studies have also demonstrated that, in disorders associated with chronic pain, poor sleep is associated with subsequent increased pain, in addition to increased pain being associated with poorer subsequent sleep $[185,186]$. Active pain treatment has been associated with improved sleep quality, with varying effects dependent 
on medications used and setting $[187,188]$. CBT-I is also a promising area in relation to improving chronic pain in older adults with insomnia [189].

\subsection{Gastro-Oesophageal Reflux Disease}

Gastro-oesophageal Reflux Disease (GORD) has been associated with insomnia and impaired sleep quality and quantity, after adjusting for multiple confounders [190]. In one cross-sectional survey, $75 \%$ of patients with nocturnal GORD symptoms stated that symptoms affected their sleep, with $42 \%$ accepting that they could not sleep through the night, and 34\% sleeping in a seated position [191]. Again, there is a possibility of a bi-directional relationship, with nocturnal GORD symptoms causing sleep arousals, and in turn, sleep disturbances exacerbating GORD via hyperalgesia and prolonged acid contact time [192]. Lifestyle interventions such as raising the head of the bed and avoiding late meal times may be beneficial [193]. Treatment with proton pump inhibitors may also be beneficial in selected patients, for both nocturnal GORD symptoms and associated sleep indices [194].

\subsection{Nocturia}

Nocturia may significantly effect sleep [195]. Severity of nocturia has been associated with poor sleep quality and reduced sleep duration [196,197]. Using objective measures, more frequent nocturia has also been associated with reduced SWS, which is thought to have an important role in cerebral restoration and recovery [198,199]. In one cross-sectional study of older patients, nocturia was found to be a more significant predictor of both poor sleep quality and insomnia than other symptoms such as pain, cough and heartburn [200].

Nocturia may be caused by benign prostatic hypertrophy (BPH), primary or secondary detrusor overactivity and pathologies associated with impaired bladder contractility [163]. In addition, excess fluid intake, diabetes mellitus, diabetes insipidus and hypercalcaemia are associated with nocturia [159]. It has also been seen in HF, HTN, venous stasis disorders, hypoalbuminemia, hepatic and renal failure $[159,163]$. This may be partially due to medications, but may also be due to atrial natriuretic peptide (ANP) and the movement of third spaced fluid of the lower extremities when patients are supine [163]. Sleep disorders and nocturia are also associated [201]. Medications associated with nocturia include diuretics, antihypertensives such as calcium channel blockers and sodium-glucose co-transporter-2 (SGLT2) inhibitors [202,203].

Determining the underlying mechanism of nocturia is the first step in management. Detailed history taking and examination is recommended. Investigations, when indicated, may include frequency volume charts, urinalysis, serum analysis (including $\mathrm{HbA1c}$, calcium, renal function, prostate-specific antigen) and measurement of post-void residual volume (PVR) [159]. Specialist referrals and cystoscopy may be required, and treatment should be tailored to the underlying cause. Lifestyle measures may be helpful, including reducing consumption of nocturnal fluid and diuretic intake, measures to prevent and reduce pedal oedema and consideration of timing, classes and formulation of medications [204,205]. Specific treatments, such as alpha 1 receptor antagonists and 5 alpha reductase inhibitors for $\mathrm{BPH}$, and bladder relaxants for those without a high PVR and symptoms suggestive of detrusor overactivity, may be helpful, while desmopressin should be considered with absolute caution due to the risk profile in older patients [204]. Given that shorter time to first void has been associated with poorer sleep quality, increasing time to first void may be helpful for sleep if nocturia cannot be eliminated [206,207].

\subsection{Parkinson's Disease}

It has been postulated that sleep and circadian dysfunction may partially drive neurodegeneration in the early phases of $\mathrm{PD}$, and that neurodegeneration may also negatively impact sleep, with a potential self-perpetuating cycle in PD [208,209]. Sleep disturbance is commonly seen in the prodromal phase of PD, prior to motor symptoms 
developing [210-212]. Good mobility on waking (sleep benefits) have also been observed in PD patients, and poor sleep has been associated with dyskinesia [213,214].

Impaired sleep in PD is likely multifactorial, related to neurodegeneration, underlying sleep disorders, PD symptoms and treatment. Nocturia is common in PD, and negatively impacts sleep continuity $[215,216]$. Nocturnal motor symptoms of PD may also contribute to impaired sleep, in addition to medications for PD, pain and depression $[217,218]$.

Treatment of sleep disruption in PD is complex. Exacerbating factors and whether underlying sleep disorders are present should be considered and treated as appropriate, with both insomnia and RBD being common in PD [219,220]. Careful consideration of PD treatment may also be of benefit. Both selegiline and amantadine, for example, have stimulant effects, and should be taken earlier in the day [221]. Excessive nocturnal dopaminergic stimulation may also result in reduced total sleep time [222,223]. This should be balanced against nocturnal motor symptoms and their effect on sleep. Levodopa-carbidopa controlled release may improve nocturnal motor symptoms that interfere with sleep, but this has not shown consistent significant improvements in sleep parameters [222,224]. Dopamine agonists have shown some benefit in relation to sleep, as a secondary endpoint in several RCTs [225]. Rotigotine's effect on sleep has been observed in small dedicated trials, with statistically significant positive effects on sleep measures [226,227]. The monoamine oxidase B inhibitor, rasagiline, as an addition to Levodopa treatment may also be beneficial in relation to sleep [228]. Hypnotics should, again, be considered with absolute caution, given their risk profile in the older population, in addition to insufficient evidence in the PD population in relation to efficacy [225,229]. Small studies of melatonin use in PD have shown promising results, and this may be due to circadian dysfunction in PD patients [230-232].

\subsection{Dementia}

There also appears to be a bi-directional relationship between dementia and sleep, with sleep disruption representing both a risk factor for, and symptom of, the neurocognitive syndrome [233-235]. A recent systematic review and metanalysis found that sleep problems, including both short and long sleep duration, insomnia, OSA, impaired circadian rhythm and sleep quality, were associated with an increased relative risk of preclinical $\mathrm{AD}$, cognitive impairment and AD [236]. Sleep disturbance also occurs commonly in AD and other forms of dementia [237]. Patients with AD can have increased sleep onset latency, and reduced time spent in restorative SWS and REM sleep [238]. Sleep disturbance may be even more common in DLB, where there is an aforementioned association with RBD [239]. Disturbed sleep may also impact carer burden and carer sleep, QOL, and is associated with a higher risk of institutionalisation [240-243].

Evidence is lacking for many commonly used medications for sleep disturbance in dementia [244]. In some cases, melatonin may be beneficial, and it may aid nocturnal behavioural and psychological symptoms of dementia (BPSD), alongside nonpharmacological interventions (which should be first line) $[245,246]$. If pharmacological intervention is deemed necessary for sleep disturbance and BPSD, trazadone may also be effective [247].

Given the risk associated with hypnotics, non-pharmacological management has an important role [229]. Evidence in this area was recently explored by $\mathrm{O}^{\prime} \mathrm{Caoimh}$ et al. in a systematic review [248]. Meta-analysis of RCTs showed a statistically significant improvement in sleep efficiency in intervention vs. control participants, but no significant difference in total sleep time, number of night-time awakenings or day time sleep duration. Looking at individual non-pharmacological categories, multi-domain interventions appeared to be associated with statistically significant improved sleep efficiency, while there was insufficient evidence to support the efficacy of light therapy. There was only one study looking at CBT-I. Patients with mild cognitive impairment (MCI) living in residential care were randomly assigned to six CBT-I sessions, or active control, and improved sleep was observed in the CBT-I group [249]. A further RCT, published following this systematic 
review, looked at dCBT-I in participants with insomnia and memory or attention complaints, but not dementia or $\mathrm{MCI}$, and showed improved cognitive and sleep outcomes in the intervention arm [250].

\subsection{Medications and Polypharmacy}

Commonly prescribed medications in the context of co-morbidity may also negatively impact sleep. Antihypertensives, antidepressants, antiepileptics, corticosteroids, decongestants and diuretics are among many medications that have been associated with insomnia, and may represent potentially inappropriate medications in the older patient [251-254]. The number of potentially inappropriate prescribed medications has also been associated with reduced sleep efficiency and sleep quality [255]. In addition, in a recent longitudinal study, patients who underwent poly-deprescribing saw significant improvements in subjective sleep quality vs. those who did not [256]. Reviewing current and recently changed medications that can contribute to sleep symptoms may be helpful in patients with sleep complaints [49]. This should also take into account the complex picture of co-morbidity management, QOL and patient preference, with particular attention to potentially inappropriate prescriptions.

\subsection{Falls}

Sleep disturbance has also been associated with falls, a major cause of morbidity and mortality in older patients $[9,257,258]$. This association appears to hold true even after adjusting for the use of hypnotics and psychotropic medications [259-262]. Increased risk of hip fractures has also been seen in patients who have sleep disturbance, with increased incidence of injurious falls seen in self-reported short and long sleep duration [263,264]. To the author's knowledge, there have been no large RCTs looking at non-pharmacological interventions to improve sleep and outcomes of falls; however, a recent multicomponent, patient-centred, phone-based RCT, with "better sleep" as one of four modules, demonstrated reduced falls and fractures in the intervention arm [265]. This is an area where further research is merited, given that impaired attention is associated with sleep impairment and falls, and nocturnal awakenings are associated with falls, non-pharmacological interventions to improve sleep may have a significant impact on the risk of falls in the geriatric population [266-269].

\subsection{Other Co-Morbidities}

Sleep disturbance and disorders have also been associated with many other comorbidities, many in potential bi-directional relationships. These include HTN, diabetes, obesity, stroke, renal disease and cancer, among others [270-275]. Exploration of further comorbidities, however, is beyond the scope of this review. Considering non-pharmacological options and optimising co-morbidity management, with cognisance of medications and interventions that can exacerbate sleep problems, is likely a reasonable general approach.

\section{General Approach and Management of Older Persons with Sleep Complaints}

The author suggests that assessment of sleep health, and further assessment where warranted, form part of every comprehensive geriatric assessment (CGA). Although there has been little validation in the older population, screening and assessment tools can be considered, with some screening and assessment tools explored in Table 2. If there appears to be an issue with sleep on initial assessment, the author suggests a systematic approach. Older patients are a heterogenous group and may suffer from several different sleep disorders, co-morbid conditions and other factors affecting sleep. Ascertaining the type of sleep issues experienced, other attendant symptoms, co-morbidities, medications, psychosocial and environmental factors are key elements of assessment [27]. Particular information should be obtained in relation to:

- Snoring or apnoeic episodes at night;

- Abnormal movement during sleep; 
- Restless leg symptoms;

- Nocturia;

- Medications and comorbidities;

- Pain;

- Psychological symptoms;

- Social circumstances;

- Sleep hygiene issues i.e., caffeine consumption, routine, light exposure, etc.

Table 2. Examples of sleep assessment/screening tools and their utility in older patients.

\begin{tabular}{|c|c|c|c|}
\hline Tool: & Purpose: & Studied in Older Populations: & Comments/Limitations: \\
\hline $\begin{array}{l}\text { Pittsburgh Sleep } \\
\text { Quality Index } \\
\text { (PSQI) [276] }\end{array}$ & $\begin{array}{l}\text { Investigates sleep quality } \\
\text { and disturbance. }\end{array}$ & $\begin{array}{l}\text { Yes, with reasonable } \\
\text { validity [276-278]. }\end{array}$ & $\begin{array}{l}\text { Can take } \geq 30 \text { min to complete and } \\
\text { requires recollections from the } \\
\text { previous month, so it may not be } \\
\text { appropriate for a geriatric clinic where } \\
\text { sleep is one of many issues being } \\
\text { addressed, or where patients suffer } \\
\text { short-term memory problems [279]. }\end{array}$ \\
\hline
\end{tabular}

\begin{tabular}{|c|c|c|c|}
\hline $\begin{array}{l}\text { Epworth Sleepiness } \\
\text { Scale } \\
\text { (ESS) [280] }\end{array}$ & $\begin{array}{l}\text { A tool to profile excessive } \\
\text { daytime sleepiness. High } \\
\text { scores of }>10 \text { are less } \\
\text { common in insomnia and } \\
\text { should trigger further } \\
\text { interrogation for another } \\
\text { sleep disorder [279]. }\end{array}$ & $\begin{array}{l}\text { Yes, with reasonable } \\
\text { validity [278]. }\end{array}$ & $\begin{array}{l}\text { Some geriatric populations } \\
\text { may find the scale } \\
\text { difficult to complete [281]. }\end{array}$ \\
\hline $\begin{array}{l}\text { Insomnia Severity } \\
\text { Index } \\
\text { (ISI) }[282]\end{array}$ & $\begin{array}{l}\text { Instrument to assess } \\
\text { insomnia severity. }\end{array}$ & $\begin{array}{l}\text { Some evidence to suggest validity } \\
\text { in the older population }[283,284] \text {. }\end{array}$ & $\begin{array}{l}\text { Applies to insomnia only and does } \\
\text { not assess sleep generally or } \\
\text { symptoms that may be relevant to } \\
\text { other sleep disorders [285]. }\end{array}$ \\
\hline $\begin{array}{l}\text { Patient-Reported } \\
\text { Outcomes Information } \\
\text { System (PROMIS) } \\
\text { Sleep Disturbance } \\
\text { Scale [286] }\end{array}$ & $\begin{array}{l}\text { The six-item scale assesses } \\
\text { perceptions of sleep quality, } \\
\text { restfulness, sleep problems } \\
\text { and difficulty falling asleep. }\end{array}$ & $\begin{array}{l}\text { Some evidence to suggest validity } \\
\text { of the six-item scale in the older } \\
\text { population [285]. }\end{array}$ & $\begin{array}{l}\text { Requires recollections from the past } \\
7 \text { days and does not assess } \\
\text { symptoms of specific sleep } \\
\text { disorders, but the overall severity of } \\
\text { sleep problems. }\end{array}$ \\
\hline $\begin{array}{l}\text { The Essener } \\
\text { Questionnaire on Age } \\
\text { and Sleepiness } \\
\text { (EQAS) [287] }\end{array}$ & $\begin{array}{l}\text { Assessment of observed } \\
\text { daytime sleepiness. }\end{array}$ & $\begin{array}{l}\text { Some evidence to suggest } \\
\text { validity, with low } \\
\text { participant numbers [287]. }\end{array}$ & $\begin{array}{l}\text { Can be filled out by carers following } \\
\text { patient observation, and may be an } \\
\text { option in patients with cognitive } \\
\text { impairment or communication } \\
\text { difficulties, although it does not } \\
\text { assess for multiple sleep disorders. }\end{array}$ \\
\hline $\begin{array}{l}\text { Berlin Questionnaire } \\
\text { (BQ) [288] }\end{array}$ & $\begin{array}{l}\text { Identify patients at risk of } \\
\text { OSA. }\end{array}$ & $\begin{array}{l}\text { Studied in an exclusively older } \\
\text { population, and was found to } \\
\text { have reduced accuracy to } \\
\text { discriminate between those with } \\
\text { and without OSA [289]. }\end{array}$ & $\begin{array}{l}\text { May have limited discriminative } \\
\text { utility in older patients, and screens } \\
\text { for OSA alone. }\end{array}$ \\
\hline $\begin{array}{c}\text { STOP-BANG } \\
\text { questionnaire [290] }\end{array}$ & $\begin{array}{l}\text { Identify patients at risk of } \\
\text { OSA. }\end{array}$ & $\begin{array}{l}\text { Recently studied in an exclusively } \\
\text { older population found to be of } \\
\text { limited utility [291]. A very high } \\
\text { proportion met OSA criteria, and } \\
\text { an argument against screening in } \\
\text { this population was made, with } \\
\text { further research needed. }\end{array}$ & $\begin{array}{l}\text { May have limited discriminative } \\
\text { utility in older patients, and screens } \\
\text { for OSA alone. }\end{array}$ \\
\hline
\end{tabular}


Table 2. Cont.

\begin{tabular}{cccc}
\hline Tool: & Purpose: & Studied in Older Populations: & Comments/Limitations: \\
\hline & & Studied in a cohort of COPD & May be an option in older patients \\
Sleep Apnoea Clinical & Identify patients at risk of \\
Score (SACS) [292] & OSA. & $\begin{array}{c}\text { patients where mean age was }>65, \\
\text { with reasonable predictive ability } \\
\text { in comparison to ESS and BQ [293]. }\end{array}$ & $\begin{array}{c}\text { with COPD, although further } \\
\text { studies are needed. }\end{array}$ \\
\hline
\end{tabular}

For restless leg syndrome and REM sleep behaviour disorder, single screening questions should be considered (see dedicated sections). BQ $=$ Berlin Questionnaire, ESS $=$ Epworth Sleepiness Scale, EQAS = The Essener Questionnaire on Age and Sleepiness, ISI = Insomnia Severity Index, OSA = obstructive sleep apnoea, PSQI = Pittsburgh Sleep Quality Index, PROMIS = Patient-Reported Outcomes Information System, SACS $=$ Sleep Apnoea Clinical Score.

Furthermore, focused physical exams and investigations may be necessary, including referrals for PSG. Assessment-based treatment for particular sleep disorders may be indicated in addition to optimising underlying co-morbidities, pain, addressing exacerbating medications, psychosocial factors and sleep hygiene [27]. A synopsis of common sleep disorder diagnosis and management and co-morbidity considerations can be found in Table 3 and Figure 1, respectively. Hypnotics, again, should only be used with absolute caution, for brief periods if thought required, and consideration of non-pharmacological options is essential.

Table 3. Synopsis of common sleep disorder diagnoses and management in the older patient.

\begin{tabular}{|c|c|c|c|}
\hline Sleep Disorder & Diagnosis & Non-Pharmacological Options & Pharmacological Options \\
\hline Insomnia & $\begin{array}{l}\text { - } \quad \text { Clinical history } \\
\text { Sleep questionnaires / } \\
\text { tools and PSG are } \\
\text { supportive }\end{array}$ & $\begin{array}{ll}\text { - } & \text { CBT-I } \\
\text { - } & \text { dCBT-I } \\
\text { - } & \text { SHE } \\
\text { - } & \text { Relaxation } \\
\text { - } & \text { Mindfulness }\end{array}$ & $\begin{array}{l}\text { - } \quad \text { Second-line/short-term } \\
\text { - } \quad \text { Dependent on patient }\end{array}$ \\
\hline $\begin{array}{l}\text { Sleep Disordered } \\
\text { Breathing }\end{array}$ & $\begin{array}{ll}- & \text { PSG } \\
- & \text { Portable home- } \\
\text { based devices }\end{array}$ & $\begin{array}{ll}\text { - } & \text { PAP } \\
\text { - Weight loss where } \\
\text { appropriate }\end{array}$ & $\begin{array}{l}\text { - Consider reduction in } \\
\text { sedating medications }\end{array}$ \\
\hline $\begin{array}{l}\text { Restless Leg } \\
\text { Syndrome }\end{array}$ & $\begin{array}{ll}\text { - } & \text { Clinical history } \\
\text { - } & \text { Screening question may } \\
\text { be helpful }\end{array}$ & - $\quad$ Limited evidence & $\begin{array}{l}\text { - } \quad \text { Iron replacement in deficiency } \\
\text { - } \quad \text { Dopamine agonists } \\
\text { channel delta calcium } \\
\text { - } \quad \text { Levodopa } \\
\text { - } \quad \begin{array}{l}\text { Benzodiazepines and opioids } \\
\text { with caution }\end{array}\end{array}$ \\
\hline $\begin{array}{c}\text { REM sleep } \\
\text { behaviour disorder }\end{array}$ & $\begin{array}{ll}\text { - } & \text { PSG } \\
\text { - } & \text { Screening question and } \\
\text { collateral may be helpful }\end{array}$ & $\begin{array}{l}\text { Modifying sleeping } \\
\text { environment if concerns } \\
\text { for injury }\end{array}$ & $\begin{array}{ll}\text { - } & \text { Review for potential } \\
\text { exacerbating medications } \\
\text { - } & \text { Limited evidence for melatonin } \\
\text { and clonazepam } \\
\text { - } \quad \text { Consider potential } \\
\text { exacerbating medications }\end{array}$ \\
\hline
\end{tabular}

CBT-I = cognitive behavioural therapy for insomnia, dCBT-I = digital cognitive behavioural therapy for insomnia, PAP = positive airway pressure therapy, PSG = polysomnography, SHE = sleep hygiene education 


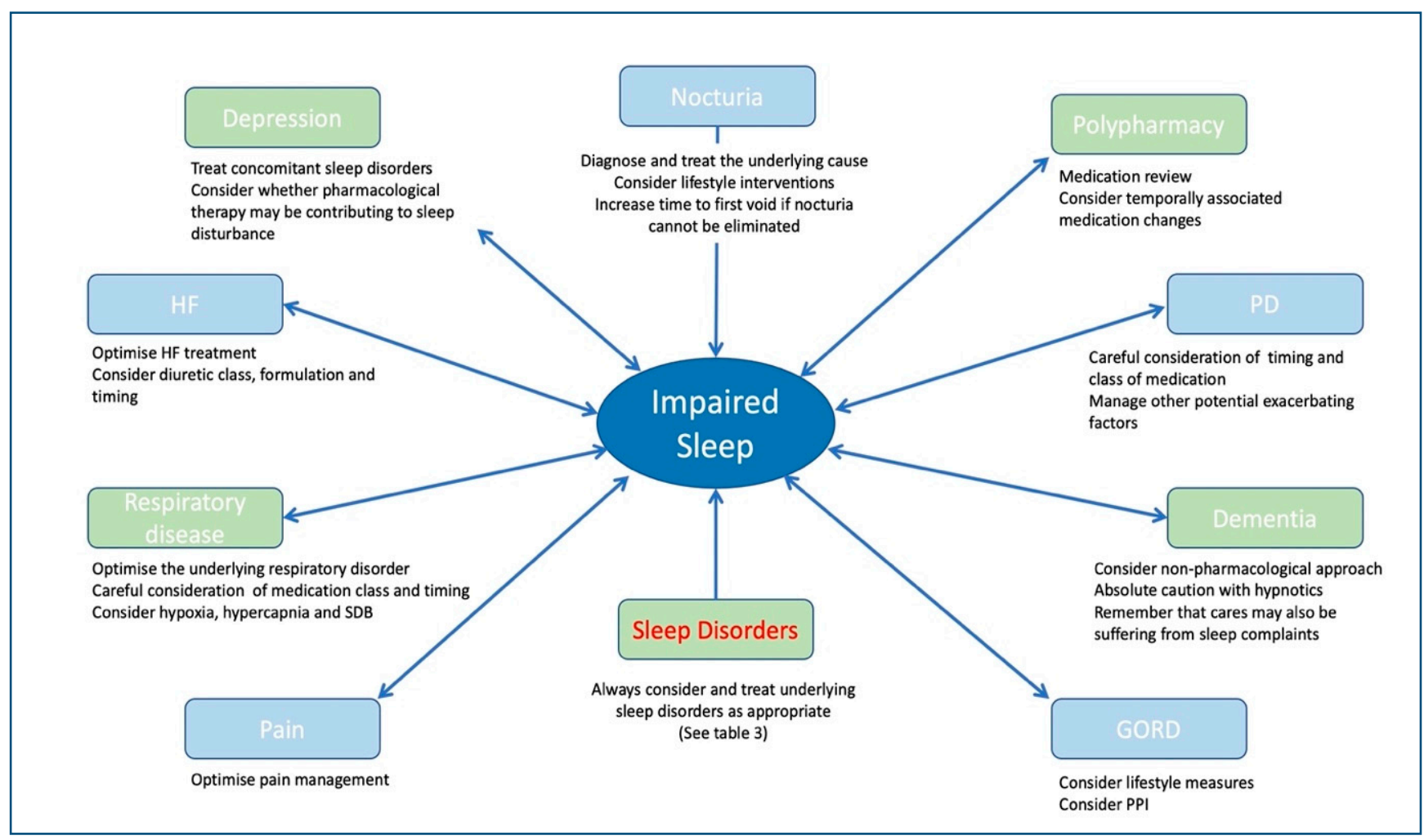

Figure 1. Summary of co-morbidities and considerations in the context of sleep complaints. HF = heart failure, GORD = gastro-oesophageal reflux disease, $\mathrm{PD}=$ Parkinson's disease, $\mathrm{SDB}=$ sleep disordered breathing.

\section{Conclusions}

Sleep complaints are both common and complex in the older person. Their consideration is an important aspect of holistic care, and may have an impact on QOL, mortality, falls and disease risk. Considering sleep disorders, co-morbidity, medication management and non-pharmacological options are important aspects of a multifaceted approach in this group. The author provides a brief overview of sleep disturbance in the context of sleep disorders and several co-morbidities, and a suggested general assessment approach that may be helpful in this complex task.

Funding: This research received no external funding.

Acknowledgments: The author would like to acknowledge the support of her colleagues at both the Galway Integrated Care Outreach Programme and the HRB-Clinical Research Facility, National University of Ireland, Galway.

Conflicts of Interest: The author has no conflict of interest to declare.

\section{References}

1. Irwin, M.R. Why Sleep Is Important for Health: A Psychoneuroimmunology Perspective. Annu. Rev. Psychol. 2015, 66, 143-172. [CrossRef] [PubMed]

2. Buxton, O.M.; Broussard, J.L.; Zahl, A.K.; Hall, M. Effects of Sleep Deficiency on Hormones, Cytokines, and Metabolism. In Impact of Sleep and Sleep Disturbances on Obesity and Cancer; Redline, S., Berger, N.A., Eds.; Springer: New York, NY, USA, 2014; pp. 25-50. [CrossRef]

3. Ohayon, M.M.; Carskadon, M.A.; Guilleminault, C.; Vitiello, M.V. Meta-Analysis of Quantitative Sleep Parameters from Childhood to Old Age in Healthy Individuals: Developing Normative Sleep Values Across the Human Lifespan. Sleep 2004, 27, 1255-1273. [CrossRef] [PubMed]

4. Brewster, G.S.; Riegel, B.; Gehrman, P.R. Insomnia in the Older Adult. Sleep Med. Clin. 2018, 13, 13-19. [CrossRef] [PubMed]

5. Dean, G.E.; Weiss, C.; Morris, J.L.; Chasens, E.R. Impaired Sleep. Nurs. Clin. N. Am. 2017, 52, 387-404. [CrossRef] [PubMed]

6. Da Silva, A.A.; de Mello, R.G.B.; Schaan, C.W.; Fuchs, F.D.; Redline, S.; Fuchs, S.C. Sleep Duration and Mortality in the Elderly: A Systematic Review with Meta-Analysis. BMJ Open 2016, 6, e008119. [CrossRef] [PubMed] 
7. Clark, A.J.; Salo, P.; Lange, T.; Jennum, P.; Virtanen, M.; Pentti, J.; Kivimäki, M.; Rod, N.H.; Vahtera, J. Onset of Impaired Sleep and Cardiovascular Disease Risk Factors: A Longitudinal Study. Sleep 2016, 39, 1709-1718. [CrossRef] [PubMed]

8. Schubert, C.R.; Cruickshanks, K.J.; Dalton, D.S.; Klein, B.E.K.; Klein, R.; Nondahl, D.M. Prevalence of Sleep Problems and Quality of Life in an Older Population. Sleep 2002, 25, 889-893.

9. Min, Y.; Slattum, P.W. Poor Sleep and Risk of Falls in Community-Dwelling Older Adults: A Systematic Review. J. Appl. Gerontol 2018, 37, 1059-1084. [CrossRef]

10. Foley, D.J.; Monjan, A.A.; Brown, S.L.; Simonsick, E.M.; Wallace, R.B.; Blazer, D.G. Sleep Complaints Among Elderly Persons: An Epidemiologic Study of Three Communities. Sleep 1995, 18, 425-432. [CrossRef]

11. Driscoll, H.C.; Serody, L.; Patrick, S.; Maurer, J.; Bensasi, S.; Houck, P.R.; Mazumdar, S.; Nofzinger, E.A.; Bell, B.; Nebes, R.D.; et al. Sleeping Well, Aging Well: A Descriptive and Cross-Sectional Study of Sleep in "Successful Agers" 75 and Older. Am. J. Geriatr. Psychiatry 2008, 16, 74-82. [CrossRef]

12. Moraes, W.; Piovezan, R.; Poyares, D.; Bittencourt, L.R.; Santos-Silva, R.; Tufik, S. Effects of Aging on Sleep Structure throughout Adulthood: A Population-Based Study. Sleep Med. 2014, 15, 401-409. [CrossRef] [PubMed]

13. Li, J.; Vitiello, M.V.; Gooneratne, N.S. Sleep in Normal Aging. Sleep Med. Clin. 2018, 13, 1-11. [CrossRef] [PubMed]

14. Zhong, H.-H.; Yu, B.; Luo, D.; Yang, L.-Y.; Zhang, J.; Jiang, S.-S.; Hu, S.-J.; Luo, Y.-Y.; Yang, M.; Hong, F.; et al. Roles of Aging in Sleep. Neurosci. Biobehav. Rev. 2019, 98, 177-184. [CrossRef] [PubMed]

15. Yan, S.; Wang, W. The Effect of Lens Aging and Cataract Surgery on Circadian Rhythm. Int. J. Ophthalmol. 2016. [CrossRef]

16. Esquiva, G.; Lax, P.; Pérez-Santonja, J.J.; García-Fernández, J.M.; Cuenca, N. Loss of Melanopsin-Expressing Ganglion Cell Subtypes and Dendritic Degeneration in the Aging Human Retina. Front. Aging Neurosci. 2017, 9. [CrossRef] [PubMed]

17. Lancel, M.; Stroebe, M.; Eisma, M.C. Sleep Disturbances in Bereavement: A Systematic Review. Sleep Med. Rev. 2020, 53, 101331. [CrossRef]

18. Pitt, B. Coping with Loss: Loss in Late Life. BMJ 1998, 316, 1452-1454. [CrossRef]

19. Li, J.; Yang, B.; Varrasse, M.; Li, K. Sleep Among Long-Term Care Residents in China: A Narrative Review of Literature. Clin. Nurs. Res. 2018, 27, 35-60. [CrossRef]

20. Tighe, C.A.; Dautovich, N.D.; McCrae, C.S. Daily Social Contact in Relation to Sleep: The Role of Age. Behav. Sleep Med. 2016, 14, 311-324. [CrossRef]

21. Mazzotti, D.R.; Guindalini, C.; Sosa, A.L.; Ferri, C.P.; Tufik, S. Prevalence and Correlates for Sleep Complaints in Older Adults in Low and Middle Income Countries: A 10/66 Dementia Research Group Study. Sleep Med. 2012, 13, 697-702. [CrossRef]

22. Li, J.; Gooneratne, N.S. Sleep and Health in Older Adults. In Sleep and Health; Elsevier: Amsterdam, The Netherlands, 2019; pp. 31-43. [CrossRef]

23. Chowdhuri, S.; Patel, P.; Badr, M.S. Apnea in Older Adults. Sleep Med. Clin. 2018, 13, 21-37. [CrossRef] [PubMed]

24. Abad, V.C.; Guilleminault, C. Review of Rapid Eye Movement Behavior Sleep Disorders. Curr. Neurol. Neurosci. Rep. 2004, 4 , 157-163. [CrossRef]

25. Taylor, D.J.; Mallory, L.J.; Lichstein, K.L.; Durrence, H.H.; Riedel, B.W.; Bush, A.J. Comorbidity of Chronic Insomnia with Medical Problems. Sleep 2007, 30, 213-218. [CrossRef] [PubMed]

26. Foley, D.; Ancoli-Israel, S.; Britz, P.; Walsh, J. Sleep Disturbances and Chronic Disease in Older Adults. J. Psychosom. Res. 2004, 56, 497-502. [CrossRef] [PubMed]

27. Bloom, H.G.; Ahmed, I.; Alessi, C.A.; Ancoli-Israel, S.; Buysse, D.J.; Kryger, M.H.; Phillips, B.A.; Thorpy, M.J.; Vitiello, M.V.; Zee, P.C. Evidence-Based Recommendations for the Assessment and Management of Sleep Disorders in Older Persons: Assessment and Management of Sleep Disorders in Older Persons. J. Am. Geriatr. Soc. 2009, 57, 761-789. [CrossRef]

28. Gulia, K.K.; Kumar, V.M. Sleep Disorders in the Elderly: A Growing Challenge: Sleep in Elderly. Psychogeriatrics 2018, 18, 155-165. [CrossRef] [PubMed]

29. American Academy of Sleep Medicine. The International Classification of Sleep Disorders, 3rd ed.; (ICSD-3); American Academy of Sleep Medicine: Darien, IL, USA, 2014.

30. Littner, M.; Hirshkowitz, M.; Kramer, M.; Kapen, S.; Anderson, W.M.; Bailey, D.; Berry, R.B.; Davila, D.; Johnson, S.; Kushida, C.; et al. Practice Parameters for Using Polysomnography to Evaluate Insomnia: An Update. Sleep 2003, 26, 754-760. [CrossRef] [PubMed]

31. Hughes, J.M.; Song, Y.; Fung, C.H.; Dzierzewski, J.M.; Mitchell, M.N.; Jouldjian, S.; Josephson, K.R.; Alessi, C.A.; Martin, J.L. Measuring Sleep in Vulnerable Older Adults: A Comparison of Subjective and Objective Sleep Measures. Clin. Gerontol. 2018, 41, 145-157. [CrossRef] [PubMed]

32. Hita-Yañez, E.; Atienza, M.; Cantero, J.L. Polysomnographic and Subjective Sleep Markers of Mild Cognitive Impairment. Sleep 2013, 36, 1327-1334. [CrossRef] [PubMed]

33. Ooms, S.; Ju, Y.-E. Treatment of Sleep Disorders in Dementia. Curr. Treat. Options Neurol. 2016, 18, 40. [CrossRef]

34. Chung, K.-F.; Lee, C.-T.; Yeung, W.-F.; Chan, M.-S.; Chung, E.W.-Y.; Lin, W.-L. Sleep Hygiene Education as a Treatment of Insomnia: A Systematic Review and Meta-Analysis. Fam. Pract. 2018, 35, 365-375. [CrossRef] [PubMed]

35. Montgomery, P. A Systematic Review of Non-Pharmacological Therapies for Sleep Problems in Later Life. Sleep Med. Rev. 2004, 8 , 47-62. [CrossRef]

36. Irwin, M.R.; Cole, J.C.; Nicassio, P.M. Comparative Meta-Analysis of Behavioral Interventions for Insomnia and Their Efficacy in Middle-Aged Adults and in Older Adults 55+ Years of Age. Health Psychol. 2006, 25, 3-14. [CrossRef] 
37. Sivertsen, B.; Omvik, S.; Pallesen, S.; Bjorvatn, B.; Havik, O.E.; Kvale, G.; Nielsen, G.H.; Nordhus, I.H. Cognitive Behavioral Therapy vs Zopiclone for Treatment of Chronic Primary Insomnia in Older Adults: A Randomized Controlled Trial. JAMA 2006, 295, 2851. [CrossRef] [PubMed]

38. Koffel, E.; Bramoweth, A.D.; Ulmer, C.S. Increasing Access to and Utilization of Cognitive Behavioral Therapy for Insomnia (CBT-I): A Narrative Review. J. Gen. Intern. Med. 2018, 33, 955-962. [CrossRef] [PubMed]

39. Salvemini, A.; D'Onofrio, G.; Ciccone, F.; Greco, A.; Tullio, A.; Addante, F.; Sancarlo, D.; Vendemiale, G.; Serviddio, G.; Ricciardi, F.; et al. Insomnia and Information and Communication Technologies (ICT) in Elderly People: A Systematic Review. Med. Sci. 2019, 7, 70. [CrossRef] [PubMed]

40. Van Maanen, A.; Meijer, A.M.; van der Heijden, K.B.; Oort, F.J. The Effects of Light Therapy on Sleep Problems: A Systematic Review and Meta-Analysis. Sleep Med. Rev. 2016, 29, 52-62. [CrossRef]

41. Richter, K.; Kellner, S.; Milosheva, L.; Fronhofen, H. Treatment of Insomnia in Elderly Patients. J. Reatt. Ther. Dev. Divers. 2020, 2, 129-138. [CrossRef]

42. Glass, J.; Lanctôt, K.L.; Herrmann, N.; Sproule, B.A.; Busto, U.E. Sedative Hypnotics in Older People with Insomnia: MetaAnalysis of Risks and Benefits. BMJ 2005, 331, 1169. [CrossRef]

43. Kang, D.-Y.; Park, S.; Rhee, C.-W.; Kim, Y.-J.; Choi, N.-K.; Lee, J.; Park, B.-J. Zolpidem Use and Risk of Fracture in Elderly Insomnia Patients. J. Prev. Med. Public Health 2012, 45, 219-226. [CrossRef]

44. Gallacher, J.; Elwood, P.; Pickering, J.; Bayer, A.; Fish, M.; Ben-Shlomo, Y. Benzodiazepine Use and Risk of Dementia: Evidence from the Caerphilly Prospective Study (CaPS). J. Epidemiol. Community Health 2012, 66, 869-873. [CrossRef] [PubMed]

45. Nguyen, K.L.; Watanabe, J.H. Association between Sleep Medications and Falls and Fall-Related Worries in Community-Dwelling Older Adults in the United States. J. Contemp. Pharm. Pract. 2020, 66, 23-32. [CrossRef]

46. Min, Y.; Nadpara, P.A.; Slattum, P.W. The Association between Sleep Problems, Sleep Medication Use, and Falls in CommunityDwelling Older Adults: Results from the Health and Retirement Study 2010. J. Aging Res. 2016, 2016, 1-10. [CrossRef] [PubMed]

47. Kripke, D.F. Hypnotic Drug Risks of Mortality, Infection, Depression, and Cancer: But Lack of Benefit. F1000Research 2018, 5, 918. [CrossRef] [PubMed]

48. Qaseem, A.; Kansagara, D.; Forciea, M.A.; Cooke, M.; Denberg, T.D.; for the Clinical Guidelines Committee of the American College of Physicians. Management of Chronic Insomnia Disorder in Adults: A Clinical Practice Guideline from the American College of Physicians. Ann. Intern. Med. 2016, 165, 125. [CrossRef]

49. Abad, V.C.; Guilleminault, C. Insomnia in Elderly Patients: Recommendations for Pharmacological Management. Drugs Aging 2018, 35, 791-817. [CrossRef]

50. Luthringer, R.; Muzet, M.; Zisapel, N.; Staner, L. The Effect of Prolonged-Release Melatonin on Sleep Measures and Psychomotor Performance in Elderly Patients with Insomnia. Int. Clin. Psychopharmacol. 2009, 24, 239-249. [CrossRef]

51. Lemoine, P.; Nir, T.; Laudon, M.; Zisapel, N. Prolonged-Release Melatonin Improves Sleep Quality and Morning Alertness in Insomnia Patients Aged 55 Years and Older and Has No Withdrawal Effects. J. Sleep Res. 2007, 16, 372-380. [CrossRef]

52. Zisapel, N. Controlled release melatonin (Circadin) in the treatment of insomnia in older patients: Efficacy and safety in patients with history of use and non-use of hypnotic drugs. Harefuah 2009, 148, 337-341.

53. Mohammadieh, A.; Sutherland, K.; Cistulli, P.A. Sleep Disordered Breathing: Management Update. Intern. Med. J. 2017, 47, 1241-1247. [CrossRef]

54. McMillan, A.; Morrell, M.J. Sleep Disordered Breathing at the Extremes of Age: The Elderly. Breathe 2016, 12, 50-60. [CrossRef] [PubMed]

55. Park, J.G.; Ramar, K.; Olson, E.J. Updates on Definition, Consequences, and Management of Obstructive Sleep Apnea. Mayo Clin. Proc. 2011, 86, 549-555. [CrossRef] [PubMed]

56. Young, T. Risk Factors for Obstructive Sleep Apnea in Adults. JAMA 2004, 291, 2013. [CrossRef] [PubMed]

57. Muza, R.T. Central Sleep Apnoea-a Clinical Review. J. Thorac. Dis. 2015, 7, 930-937. [CrossRef] [PubMed]

58. Edwards, B.A.; Wellman, A.; Sands, S.A.; Owens, R.L.; Eckert, D.J.; White, D.P.; Malhotra, A. Obstructive Sleep Apnea in Older Adults Is a Distinctly Different Physiological Phenotype. Sleep 2014, 37, 1227-1236. [CrossRef]

59. Chung, S.; Yoon, I.-Y.; Lee, C.H.; Kim, J.-W. Effects of Age on the Clinical Features of Men with Obstructive Sleep Apnea Syndrome. Respiration 2009, 78, 23-29. [CrossRef]

60. Morrell, M.J.; Finn, L.; McMillan, A.; Peppard, P.E. The Impact of Ageing and Sex on the Association between Sleepiness and Sleep Disordered Breathing. Eur. Respir. J. 2012, 40, 386-393. [CrossRef]

61. Launois, S.H.; Pépin, J.-L.; Lévy, P. Sleep Apnea in the Elderly: A Specific Entity? Sleep Med. Rev. 2007, 11, 87-97. [CrossRef]

62. Amra, B.; Rahmati, B.; Soltaninejad, F.; Feizi, A. Screening Questionnaires for Obstructive Sleep Apnea: An Updated Systematic Review. Oman Med. J. 2018, 33, 184-192. [CrossRef]

63. El Shayeb, M.; Topfer, L.-A.; Stafinski, T.; Pawluk, L.; Menon, D. Diagnostic Accuracy of Level 3 Portable Sleep Tests versus Level 1 Polysomnography for Sleep-Disordered Breathing: A Systematic Review and Meta-Analysis. Can. Med. Assoc. J. 2014, 186, E25-E51. [CrossRef]

64. Morales, C.R.; Hurley, S.; Wick, L.C.; Staley, B.; Pack, F.M.; Gooneratne, N.S.; Maislin, G.; Pack, A.; Gurubhagavatula, I. In-Home, Self-Assembled Sleep Studies Are Useful in Diagnosing Sleep Apnea in the Elderly. Sleep 2012. [CrossRef]

65. Polese, J.F.; Santos-Silva, R.; de Oliveira Ferrari, P.M.; Sartori, D.E.; Tufik, S.; Bittencourt, L. Is Portable Monitoring for Diagnosing Obstructive Sleep Apnea Syndrome Suitable in Elderly Population? Sleep Breath 2013, 17, 679-686. [CrossRef] [PubMed] 
66. Munoz, R.; Duran-Cantolla, J.; Martínez-Vila, E.; Gallego, J.; Rubio, R.; Aizpuru, F.; De La Torre, G. Severe Sleep Apnea and Risk of Ischemic Stroke in the Elderly. Stroke 2006, 37, 2317-2321. [CrossRef] [PubMed]

67. Muñoz, R.; Durán-Cantolla, J.; Martinez-Vila, E.; Gállego, J.; Rubio, R.; Aizpuru, F.; De La Torre, G.; Barbé, F. Central Sleep Apnea Is Associated with Increased Risk of Ischemic Stroke in the Elderly: Central Sleep Apnea and Risk of Stroke in the Elderly. Acta Neurol. Scand. 2012, 126, 183-188. [CrossRef]

68. Onen, S.-H.; Lesourd, B.; Ouchchane, L.; Lin, J.-S.; Dubray, C.; Gooneratne, N.S.; Onen, F. Occult Nighttime Hypertension in Daytime Normotensive Older Patients With Obstructive Sleep Apnea. J. Am. Med. Dir. Assoc. 2012, 13, 752-756. [CrossRef]

69. Onen, S.H.; Mouriaux, F.; Berramdane, L.; Dascotte, J.-C.; Kulik, J.-F.; Rouland, J.-F. High Prevalence of Sleep-Disordered Breathing in Patients with Primary Open-Angle Glaucoma. Acta Ophthalmol. Scand. 2000, 78, 638-641. [CrossRef] [PubMed]

70. Onen, F.; Higgins, S.; Onen, S.-H. Falling-Asleep-Related Injured Falls in the Elderly. J. Am. Med. Dir. Assoc. 2009, 10, 207-210. [CrossRef]

71. Gooneratne, N.S.; Richards, K.C.; Joffe, M.; Lam, R.W.; Pack, F.; Staley, B.; Dinges, D.F.; Pack, A.I. Sleep Disordered Breathing with Excessive Daytime Sleepiness Is a Risk Factor for Mortality in Older Adults. Sleep 2011, 34, 435-442. [CrossRef]

72. Virgine Dauphinot, H.O.S. Morbidity and Predicted Mortality in Older Adults with Central Sleep Apnea. J. Sleep Disord. Ther. 2013, 2. [CrossRef]

73. Leng, Y.; McEvoy, C.T.; Allen, I.E.; Yaffe, K. Association of Sleep-Disordered Breathing with Cognitive Function and Risk of Cognitive Impairment: A Systematic Review and Meta-Analysis. JAMA Neurol. 2017, 74, 1237. [CrossRef]

74. Netzer, N.C.; Ancoli-Israel, S.; Bliwise, D.L.; Fulda, S.; Roffe, C.; Almeida, F.; Onen, H.; Onen, F.; Raschke, F.; Martinez Garcia, M.A.; et al. Principles of Practice Parameters for the Treatment of Sleep Disordered Breathing in the Elderly and Frail Elderly: The Consensus of the International Geriatric Sleep Medicine Task Force. Eur. Respir. J. 2016, 48, 992-1018. [CrossRef] [PubMed]

75. Ancoli-Israel, S.; Palmer, B.W.; Cooke, J.R.; Corey-Bloom, J.; Fiorentino, L.; Natarajan, L.; Liu, L.; Ayalon, L.; He, F.; Loredo, J.S. Cognitive Effects of Treating Obstructive Sleep Apnea in Alzheimer's Disease: A Randomized Controlled Study: Effect of Treating Osa on Cognition in Ad. J. Am. Geriatr. Soc. 2008, 56, 2076-2081. [CrossRef] [PubMed]

76. Zimmerman, M.E.; Arnedt, J.T.; Stanchina, M.; Millman, R.P.; Aloia, M.S. Normalization of Memory Performance and Positive Airway Pressure Adherence in Memory-Impaired Patients with Obstructive Sleep Apnea. Chest 2006, 130, $1772-1778$. [CrossRef] [PubMed]

77. Cooke, J.R.; Ayalon, L.; Palmer, B.W.; Loredo, J.S.; Corey-Bloom, J.; Natarajan, L.; Liu, L.; Ancoli-Israel, S. Sustained Use of CPAP Slows Deterioration of Cognition, Sleep, and Mood in Patients with Alzheimer's Disease and Obstructive Sleep Apnea: A Preliminary Study. J. Clin. Sleep Med. 2009, 5, 305-309. [CrossRef] [PubMed]

78. Nishihata, Y.; Takata, Y.; Usui, Y.; Kato, K.; Yamaguchi, T.; Shiina, K.; Yamashina, A. Continuous Positive Airway Pressure Treatment Improves Cardiovascular Outcomes in Elderly Patients with Cardiovascular Disease and Obstructive Sleep Apnea. Heart Vessel. 2015, 30, 61-69. [CrossRef] [PubMed]

79. Bravata, D.M.; Concato, J.; Fried, T.; Ranjbar, N.; Sadarangani, T.; McClain, V.; Struve, F.; Zygmunt, L.; Knight, H.J.; Lo, A.; et al. Continuous Positive Airway Pressure: Evaluation of a Novel Therapy for Patients with Acute Ischemic Stroke. Sleep 2011, 34, 1271-1277. [CrossRef] [PubMed]

80. Martínez-García, M.A.; Galiano-Blancart, R.; Román-Sánchez, P.; Soler-Cataluña, J.-J.; Cabero-Salt, L.; Salcedo-Maiques, E. Continuous Positive Airway Pressure Treatment in Sleep Apnea Prevents New Vascular Events after Ischemic Stroke. Chest 2005, 128, 2123-2129. [CrossRef] [PubMed]

81. Martínez-García, M.Á.; Chiner, E.; Hernández, L.; Cortes, J.P.; Catalán, P.; Ponce, S.; Diaz, J.R.; Pastor, E.; Vigil, L.; Carmona, C.; et al. Obstructive Sleep Apnoea in the Elderly: Role of Continuous Positive Airway Pressure Treatment. Eur. Respir. J. 2015, 46, 142-151. [CrossRef]

82. Yagihara, F.; Lucchesi, L.M.; D'Almeida, V.; de Mello, M.T.; Tufik, S.; Bittencourt, L.R.A. Oxidative Stress and Quality of Life in Elderly Patients with Obstructive Sleep Apnea Syndrome: Are There Differences after Six Months of Continuous Positive Airway Pressure Treatment? Clinics 2012, 67, 565-572. [CrossRef]

83. Sawyer, A.M.; Gooneratne, N.S.; Marcus, C.L.; Ofer, D.; Richards, K.C.; Weaver, T.E. A Systematic Review of CPAP Adherence across Age Groups: Clinical and Empiric Insights for Developing CPAP Adherence Interventions. Sleep Med. Rev. 2011, 15, 343-356. [CrossRef]

84. Ayalon, L.; Ancoli-Israel, S.; Stepnowsky, C.; Marler, M.; Palmer, B.W.; Liu, L.; Loredo, J.S.; Corey-Bloom, J.; Greenfield, D.; Cooke, J. Adherence to Continuous Positive Airway Pressure Treatment in Patients with Alzheimer Disease and Obstructive Sleep Apnea. Am. J. Geriatr. Psychiatry 2006, 14, 176-180. [CrossRef] [PubMed]

85. Winkelman, J.W.; Armstrong, M.J.; Allen, R.P.; Chaudhuri, K.R.; Ondo, W.; Trenkwalder, C.; Zee, P.C.; Gronseth, G.S.; Gloss, D.; Zesiewicz, T. Practice Guideline Summary: Treatment of Restless Legs Syndrome in Adults: Table: Report of the Guideline Development, Dissemination, and Implementation Subcommittee of the American Academy of Neurology. Neurology 2016, 87, 2585-2593. [CrossRef] [PubMed]

86. Guo, S.; Huang, J.; Jiang, H.; Han, C.; Li, J.; Xu, X.; Zhang, G.; Lin, Z.; Xiong, N.; Wang, T. Restless Legs Syndrome: From Pathophysiology to Clinical Diagnosis and Management. Front. Aging Neurosci. 2017, 9, 171. [CrossRef] [PubMed]

87. Ferri, R.; Lanuzza, B.; Cosentino, F.I.I.; Iero, I.; Tripodi, M.; Spada, R.S.; Toscano, G.; Marelli, S.; Aricò, D.; Bella, R.; et al. A Single Question for the Rapid Screening of Restless Legs Syndrome in the Neurological Clinical Practice. Eur. J. Neurol. 2007, 14, 1016-1021. [CrossRef] 
88. Allen, R.P.; Picchietti, D.L.; Garcia-Borreguero, D.; Ondo, W.G.; Walters, A.S.; Winkelman, J.W.; Zucconi, M.; Ferri, R.; Trenkwalder, C.; Lee, H.B. Restless Legs Syndrome/Willis-Ekbom Disease Diagnostic Criteria: Updated International Restless Legs Syndrome Study Group (IRLSSG) Consensus Criteria-History, Rationale, Description, and Significance. Sleep Med. 2014, 15, 860-873. [CrossRef] [PubMed]

89. Ohayon, M.M.; O’Hara, R.; Vitiello, M.V. Epidemiology of Restless Legs Syndrome: A Synthesis of the Literature. Sleep Med. Rev. 2012, 16, 283-295. [CrossRef] [PubMed]

90. Zucconi, M.; Manconi, M.; Ferini Strambi, L. Aetiopathogenesis of Restless Legs Syndrome. Neurol. Sci. 2007, 28 (Suppl. S1), S47-S52. [CrossRef] [PubMed]

91. Allen, R.P. Controversies and Challenges in Defining the Etiology and Pathophysiology of Restless Legs Syndrome. Am. J. Med. 2007, 120, S13-S21. [CrossRef] [PubMed]

92. Trenkwalder, C.; Allen, R.; Högl, B.; Clemens, S.; Patton, S.; Schormair, B.; Winkelmann, J. Comorbidities, Treatment, and Pathophysiology in Restless Legs Syndrome. Lancet Neurol. 2018, 17, 994-1005. [CrossRef]

93. Li, Y.; Li, Y.; Winkelman, J.W.; Walters, A.S.; Han, J.; Hu, F.B.; Gao, X. Prospective Study of Restless Legs Syndrome and Total and Cardiovascular Mortality among Women. Neurology 2018, 90, e135-e141. [CrossRef]

94. Hornyak, M. Depressive Disorders in Restless Legs Syndrome: Epidemiology, Pathophysiology and Management. CNS Drugs 2010, 24, 89-98. [CrossRef] [PubMed]

95. Hening, W. Impact, Diagnosis and Treatment of Restless Legs Syndrome (RLS) in a Primary Care Population: The REST (RLS Epidemiology, Symptoms, and Treatment) Primary Care Study. Sleep Med. 2004, 5, 237-246. [CrossRef]

96. Phillips, B.; Hening, W.; Britz, P.; Mannino, D. Prevalence and Correlates of Restless Legs Syndrome. Chest 2006, 129, 76-80. [CrossRef] [PubMed]

97. Allen, R.P.; Walters, A.S.; Montplaisir, J.; Hening, W.; Myers, A.; Bell, T.J.; Ferini-Strambi, L. Restless Legs Syndrome Prevalence and Impact: REST General Population Study. Arch. Intern. Med. 2005, 165, 1286. [CrossRef] [PubMed]

98. Cuellar, N.G.; Strumpf, N.E.; Ratcliffe, S.J. Symptoms of Restless Legs Syndrome in Older Adults: Outcomes on Sleep Quality, Sleepiness, Fatigue, Depression, and Quality of Life: Effects of Symptom Severity of Rls in Older Adults. J. Am. Geriatr. Soc. 2007, 55, 1387-1392. [CrossRef] [PubMed]

99. Harrison, E.G.; Keating, J.L.; Morgan, P.E. Non-Pharmacological Interventions for Restless Legs Syndrome: A Systematic Review of Randomised Controlled Trials. Disabil. Rehabil. 2019, 41, 2006-2014. [CrossRef]

100. Kolla, B.P.; Mansukhani, M.P.; Bostwick, J.M. The Influence of Antidepressants on Restless Legs Syndrome and Periodic Limb Movements: A Systematic Review. Sleep Med. Rev. 2018, 38, 131-140. [CrossRef] [PubMed]

101. Comella, C.L. Treatment of Restless Legs Syndrome. Neurotherapeutics 2014, 11, 177-187. [CrossRef] [PubMed]

102. Earley, C.J. The Importance of Oral Iron Therapy in Restless Legs Syndrome. Sleep Med. 2009, 10, 945-946. [CrossRef]

103. Cho, Y.W.; Allen, R.P.; Earley, C.J. Lower Molecular Weight Intravenous Iron Dextran for Restless Legs Syndrome. Sleep Med. 2013, 14, 274-277. [CrossRef]

104. Wang, J.; O’Reilly, B.; Venkataraman, R.; Mysliwiec, V.; Mysliwiec, A. Efficacy of Oral Iron in Patients with Restless Legs Syndrome and a Low-Normal Ferritin: A Randomized, Double-Blind, Placebo-Controlled Study. Sleep Med. 2009, 10, 973-975. [CrossRef]

105. De Franceschi, L.; Iolascon, A.; Taher, A.; Cappellini, M.D. Clinical Management of Iron Deficiency Anemia in Adults: Systemic Review on Advances in Diagnosis and Treatment. Eur. J. Intern. Med. 2017, 42, 16-23. [CrossRef]

106. Madhusoodanan, S.; Bogunovic, O.J. Safety of Benzodiazepines in the Geriatric Population. Expert Opin. Drug Saf. 2004, 3, 485-493. [CrossRef]

107. Wilder-Smith, O.H.G. Opioid Use in the Elderly. Eur. J. Pain 2005, 9, 137-140. [CrossRef]

108. Zhang, W.; Wang, C.; Nao, J.F.; Feng, J.; Bi, G.R. Efficacy and Tolerability of Pramipexole for the Treatment of Primary Restless Leg Syndrome: A Meta-Analysis of Randomized Placebo-Controlled Trials. NDT 2013, 9, 1035-1043. [CrossRef] [PubMed]

109. Hansen, R.A.; Song, L.; Moore, C.G.; Gilsenan, A.W.; Kim, M.M.; Calloway, M.O.; Murray, M.D. Effect of Ropinirole on Sleep Outcomes in Patients with Restless Legs Syndrome: Meta-Analysis of Pooled Individual Patient Data from Randomized Controlled Trials. Pharmacotherapy 2009, 29, 255-262. [CrossRef]

110. Beneš, H.; Kurella, B.; Kummer, J.; Kazenwadel, J.; Selzer, R.; Kohnen, R. Rapid Onset of Action of Levodopa in Restless Legs Syndrome: A Double-Blind, Randomized, Multicenter, Crossover Trial. Sleep 1999, 22, 1073-1081. [CrossRef]

111. Trenkwalder, C.; Stiasny, K.; Pollmächer, T.; Wetter, T.; Schwarz, J.; Kohnen, R.; Kazenwadel, J.; Krüger, H.P.; Ramm, S.; Küinzel, M.; et al. L-Dopa Therapy of Uremic and Idiopathic Restless Legs Syndrome: A Double-Blind, Crossover Trial. Sleep 1995, 18, 681-688. [CrossRef]

112. Kushida, C.A.; Walters, A.S.; Becker, P.; Thein, S.G.; Perkins, A.T.; Roth, T.; Canafax, D.; Barrett, R.W.; The XP021 Study Group. A Randomized, Double-Blind, Placebo-Controlled, Crossover Study of Xp13512/Gsk1838262 in the Treatment of Patients with Primary Restless Legs Syndrome. Sleep 2009, 32, 159-168. [CrossRef] [PubMed]

113. Walters, A.S.; Ondo, W.G.; Kushida, C.A.; Becker, P.M.; Ellenbogen, A.L.; Canafax, D.M.; Barrett, R.W. Gabapentin Enacarbil in Restless Legs Syndrome: A Phase 2b, 2-Week, Randomized, Double-Blind, Placebo-Controlled Trial. Clin. Neuropharmacol. 2009, 32, 311-320. [CrossRef] [PubMed]

114. Kushida, C.A.; Becker, P.M.; Ellenbogen, A.L.; Canafax, D.M.; Barrett, R.W.; The XP052 Study Group. Randomized, Double-Blind, Placebo-Controlled Study of XP13512/GSK1838262 in Patients with RLS. Neurology 2009, 72, 439-446. [CrossRef] [PubMed] 
115. Lee, D.O.; Ziman, R.B.; Perkins, A.T.; Poceta, J.S.; Walters, A.S.; Barrett, R.W.; XP053 Study Group. A Randomized, Double-Blind, Placebo-Controlled Study to Assess the Efficacy and Tolerability of Gabapentin Enacarbil in Subjects with Restless Legs Syndrome. J. Clin. Sleep Med. 2011, 07, 282-292. [CrossRef] [PubMed]

116. Allen, R.; Chen, C.; Soaita, A.; Wohlberg, C.; Knapp, L.; Peterson, B.T.; García-Borreguero, D.; Miceli, J. A Randomized, DoubleBlind, 6-Week, Dose-Ranging Study of Pregabalin in Patients with Restless Legs Syndrome. Sleep Med. 2010, 11, 512-519. [CrossRef] [PubMed]

117. Fernández-Arcos, A.; Iranzo, A.; Serradell, M.; Gaig, C.; Santamaria, J. The Clinical Phenotype of Idiopathic Rapid Eye Movement Sleep Behavior Disorder at Presentation: A Study in 203 Consecutive Patients. Sleep 2016, 39, 121-132. [CrossRef]

118. Iranzo, A.; Santamaria, J.; Tolosa, E. Idiopathic Rapid Eye Movement Sleep Behaviour Disorder: Diagnosis, Management, and the Need for Neuroprotective Interventions. Lancet Neurol. 2016, 15, 405-419. [CrossRef]

119. Haba-Rubio, J.; Frauscher, B.; Marques-Vidal, P.; Toriel, J.; Tobback, N.; Andries, D.; Preisig, M.; Vollenweider, P.; Postuma, R.; Heinzer, R. Prevalence and Determinants of Rapid Eye Movement Sleep Behavior Disorder in the General Population. Sleep 2018, 41. [CrossRef] [PubMed]

120. Kim, K.T.; Motamedi, G.K.; Cho, Y.W. Quality of Life in Patients with an Idiopathic Rapid Eye Movement Sleep Behaviour Disorder in Korea. J. Sleep Res. 2017, 26, 422-427. [CrossRef]

121. McCarter, S.J.; St. Louis, E.K.; Boswell, C.L.; Dueffert, L.G.; Slocumb, N.; Boeve, B.F.; Silber, M.H.; Olson, E.J.; Morgenthaler, T.I.; Tippmann-Peikert, M. Factors Associated with Injury in REM Sleep Behavior Disorder. Sleep Med. 2014, 15, 1332-1338. [CrossRef]

122. Comella, C.L.; Nardine, T.M.; Diederich, N.J.; Stebbins, G.T. Sleep-Related Violence, Injury, and REM Sleep Behavior Disorder in Parkinson's Disease. Neurology 1998, 51, 526-529. [CrossRef]

123. Schenck, C.H.; Boeve, B.F.; Mahowald, M.W. Delayed Emergence of a Parkinsonian Disorder or Dementia in $81 \%$ of Older Men Initially Diagnosed with Idiopathic Rapid Eye Movement Sleep Behavior Disorder: A 16-Year Update on a Previously Reported Series. Sleep Med. 2013, 14, 744-748. [CrossRef]

124. Iranzo, A.; Fernández-Arcos, A.; Tolosa, E.; Serradell, M.; Molinuevo, J.L.; Valldeoriola, F.; Gelpi, E.; Vilaseca, I.; Sánchez-Valle, R.; Lladó, A.; et al. Neurodegenerative Disorder Risk in Idiopathic REM Sleep Behavior Disorder: Study in 174 Patients. PLoS ONE 2014, 9, e89741. [CrossRef] [PubMed]

125. Weil, R.S.; Morris, H.R. REM Sleep Behaviour Disorder: An Early Window for Prevention in Neurodegeneration? Brain 2019, 142, 498-501. [CrossRef]

126. Gjerstad, M.D.; Alves, G.; Maple-Grødem, J. Excessive Daytime Sleepiness and REM Sleep Behavior Disorders in Parkinson's Disease: A Narrative Review on Early Intervention with Implications to Neuroprotection. Front. Neurol. $2018,9,961$. [CrossRef] [PubMed]

127. Postuma, R.B.; Arnulf, I.; Hogl, B.; Iranzo, A.; Miyamoto, T.; Dauvilliers, Y.; Oertel, W.; Ju, Y.-E.; Puligheddu, M.; Jennum, P.; et al. A Single-Question Screen for Rapid Eye Movement Sleep Behavior Disorder: A Multicenter Validation Study: REM Sleep Behavior Disorder Screen. Mov. Disord. 2012, 27, 913-916. [CrossRef] [PubMed]

128. Boeve, B.F.; Molano, J.R.; Ferman, T.J.; Lin, S.-C.; Bieniek, K.; Tippmann-Peikert, M.; Boot, B.; St Louis, E.K.; Knopman, D.S.; Petersen, R.C.; et al. Validation of the Mayo Sleep Questionnaire to Screen for REM Sleep Behavior Disorder in a CommunityBased Sample. J. Clin. Sleep Med. 2013, 9, 475-480. [CrossRef] [PubMed]

129. Matar, E.; Lewis, S.J. REM Sleep Behaviour Disorder: Not Just a Bad Dream. Med. J. Aust. 2017, 207, 262-268. [CrossRef] [PubMed]

130. Reading, P.; Wilson, S.J. Pharmacological Treatment of Insomnia and Parasomnias. In Sleep Disorders in Neurology; Overeem, S., Reading, P., Eds.; John Wiley \& Sons, Ltd.: Chichester, UK, 2018; pp. 61-72. [CrossRef]

131. Li, S.X.; Lam, S.P.; Zhang, J.; Yu, M.W.M.; Chan, J.W.Y.; Liu, Y.; Lam, V.K.H.; Ho, C.K.W.; Zhou, J.; Wing, Y.K. A Prospective, Naturalistic Follow-up Study of Treatment Outcomes with Clonazepam in Rapid Eye Movement Sleep Behavior Disorder. Sleep Med. 2016, 21, 114-120. [CrossRef]

132. Jun, J.; Kim, R.; Byun, J.; Kim, T.; Lim, J.; Sunwoo, J.; Lee, S.; Jung, K.; Park, K.; Chu, K.; et al. Prolonged-Release Melatonin in Patients with Idiopathic REM Sleep Behavior Disorder. Ann. Clin. Transl. Neurol. 2019, 6, 716-722. [CrossRef]

133. Shin, C.; Park, H.; Lee, W.-W.; Kim, H.-J.; Kim, H.-J.; Jeon, B. Clonazepam for Probable REM Sleep Behavior Disorder in Parkinson's Disease: A Randomized Placebo-Controlled Trial. J. Neurol. Sci. 2019, 401, 81-86. [CrossRef]

134. Gilat, M.; Coeytaux Jackson, A.; Marshall, N.S.; Hammond, D.; Mullins, A.E.; Hall, J.M.; Fang, B.A.M.; Yee, B.J.; Wong, K.K.H.; Grunstein, R.R.; et al. Melatonin for Rapid Eye Movement Sleep Behavior Disorder in Parkinson's Disease: A Randomised Controlled Trial. Mov. Disord. 2020, 35, 344-349. [CrossRef]

135. Aurora, R.N.; Zak, R.S.; Maganti, R.K.; Auerbach, S.H.; Casey, K.R.; Chowdhuri, S.; Karippot, A.; Ramar, K.; Kristo, D.A.; Morgenthaler, T.I.; et al. Best Practice Guide for the Treatment of REM Sleep Behavior Disorder (RBD). J. Clin. Sleep Med. 2010, 6, 85-95. [PubMed]

136. Gallo, J.J.; Anthony, J.C.; Muthen, B.O. Age Differences in the Symptoms of Depression: A Latent Trait Analysis. J. Gerontol. 1994, 49, P251-P264. [CrossRef] [PubMed]

137. Fiske, A.; Wetherell, J.L.; Gatz, M. Depression in Older Adults. Annu. Rev. Clin. Psychol. 2009, 5, 363-389. [CrossRef] [PubMed]

138. Rodin, J.; McAvay, G.; Timko, C. A Longitudinal Study of Depressed Mood and Sleep Disturbances in Elderly Adults. J. Gerontol. 1988, 43, P45-P53. [CrossRef] [PubMed]

139. Fang, H.; Tu, S.; Sheng, J.; Shao, A. Depression in Sleep Disturbance: A Review on a Bidirectional Relationship, Mechanisms and Treatment. J. Cell Mol. Med. 2019, 23, 2324-2332. [CrossRef] 
140. Manber, R.; Edinger, J.D.; Gress, J.L.; Pedro-Salcedo, M.G.S.; Kuo, T.F.; Kalista, T. Cognitive Behavioral Therapy for Insomnia Enhances Depression Outcome in Patients with Comorbid Major Depressive Disorder and Insomnia. Sleep 2008, 31, 489-495. [CrossRef]

141. Sadler, P.; McLaren, S.; Klein, B.; Harvey, J.; Jenkins, M. Cognitive Behavior Therapy for Older Adults with Insomnia and Depression: A Randomized Controlled Trial in Community Mental Health Services. Sleep 2018, 41. [CrossRef]

142. Doghramji, K.; Jangro, W.C. Adverse Effects of Psychotropic Medications on Sleep. Psychiatr. Clin. N. Am. 2016, 39, 487-502. [CrossRef]

143. Hashimoto, T.; Shiina, A.; Hasegawa, T.; Kimura, H.; Oda, Y.; Niitsu, T.; Ishikawa, M.; Tachibana, M.; Muneoka, K.; Matsuki, S.; et al. Effect of Mirtazapine versus Selective Serotonin Reuptake Inhibitors on Benzodiazepine Use in Patients with Major Depressive Disorder: A Pragmatic, Multicenter, Open-Label, Randomized, Active-Controlled, 24-Week Trial. Ann. Gen. Psychiatry 2016, 15, 27. [CrossRef]

144. Winokur, A.; Sateia, M.J.; Hayes, J.B.; Bayles-Dazet, W.; MacDonald, M.M.; Gary, K.A. Acute Effects of Mirtazapine on Sleep Continuity and Sleep Architecture in Depressed Patients: A Pilot Study. Biol. Psychiatry 2000, 48, 75-78. [CrossRef]

145. Mouret, J.; Lemoine, P.; Minuit, M.P.; Benkelfat, C.; Renardet, M. Effects of Trazodone on the Sleep of Depressed Subjects? A Polygraphic Study. Psychopharmacology 1988, 95. [CrossRef] [PubMed]

146. Salva, M.-A.Q.; Vanier, B.; Laredo, J.; Hartley, S.; Chapotot, F.; Moulin, C.; Lofaso, F.; Guilleminault, C. Major Depressive Disorder, Sleep EEG and Agomelatine: An Open-Label Study. Int. J. Neuropsychopharm. 2007, 10. [CrossRef]

147. Norman, T.R.; Olver, J.S. Agomelatine for Depression: Expanding the Horizons? Expert Opin. Pharmacother. 2019, 20, 647-656. [CrossRef] [PubMed]

148. Broström, A.; Strömberg, A.; Dahlström, U.; Fridlund, B. Sleep Difficulties, Daytime Sleepiness, and Health-Related Quality of Life in Patients with Chronic Heart Failure. J. Cardiovasc. Nurs. 2004, 19, 234-242. [CrossRef]

149. On Behalf of the Italian Society of Cardiology (SIC) Working Group on Heart Failure Members; Parati, G.; Lombardi, C.; Castagna, F.; Mattaliano, P.; Filardi, P.P.; Agostoni, P. Heart Failure and Sleep Disorders. Nat. Rev. Cardiol. 2016, 13, $389-403$. [CrossRef] [PubMed]

150. Kasai, T.; Floras, J.S.; Bradley, T.D. Sleep Apnea and Cardiovascular Disease: A Bidirectional Relationship. Circulation 2012, 126, 1495-1510. [CrossRef]

151. Redeker, N.S.; Jeon, S.; Muench, U.; Campbell, D.; Walsleben, J.; Rapoport, D.M. Insomnia Symptoms and Daytime Function in Stable Heart Failure. Sleep 2010, 33, 1210-1216. [CrossRef]

152. Hayes, D.; Anstead, M.I.; Ho, J.; Phillips, B.A. Insomnia and Chronic Heart Failure. Heart Fail. Rev. 2009, 14, 171-182. [CrossRef]

153. Nagai, M.; Hoshide, S.; Kario, K. Sleep Duration as a Risk Factor for Cardiovascular Disease-a Review of the Recent Literature. CCR 2010, 6, 54-61. [CrossRef]

154. Yoshihisa, A.; Takeishi, Y. Sleep Disordered Breathing and Cardiovascular Diseases. JAT 2019, 26, 315-327. [CrossRef]

155. Pan, S.; Cabral, C.S.; Ashley, E.A.; Perez, M.V. Orexin: A Missing Link between Sleep Disorders and Heart Failure? Curr. Heart Fail. Rep. 2017, 14, 100-105. [CrossRef] [PubMed]

156. Herr, J.K.; Salyer, J.; Lyon, D.E.; Goodloe, L.; Schubert, C.; Clement, D.G. Heart Failure Symptom Relationships: A Systematic Review. J. Cardiovasc. Nurs. 2014, 29, 416-422. [CrossRef]

157. Zuurbier, L.A.; Luik, A.I.; Leening, M.J.G.; Hofman, A.; Freak-Poli, R.; Franco, O.H.; Stricker, B.H.; Tiemeier, H. Associations of Heart Failure with Sleep Quality: The Rotterdam Study. J. Clin. Sleep Med. 2015, 11, 117-121. [CrossRef] [PubMed]

158. Redeker, N.S.; Adams, L.; Berkowitz, R.; Blank, L.; Freudenberger, R.; Gilbert, M.; Walsleben, J.; Zucker, M.J.; Rapoport, D. Nocturia, Sleep and Daytime Function in Stable Heart Failure. J. Card. Fail. 2012, 18, 569-575. [CrossRef] [PubMed]

159. Oelke, M.; De Wachter, S.; Drake, M.J.; Giannantoni, A.; Kirby, M.; Orme, S.; Rees, J.; van Kerrebroeck, P.; Everaert, K. A Practical Approach to the Management of Nocturia. Int. J. Clin. Pract. 2017, 71, e13027. [CrossRef]

160. Gundersen, T.; Wiklund, I.; Swedberg, K.; Amtorp, O.; Remes, J.; Nilsson, B.; the Ramipril Study Group. Effects of 12 Weeks of Ramipril Treatment on the Quality of Life in Patients with Moderate Congestive Heart Failure: Results of a Placebo-Controlled Trial. Cardiovasc. Drug Ther. 1995, 9, 589-594. [CrossRef] [PubMed]

161. Walsh, J.T.; Andrews, R.; Starling, R.; Cowley, A.J.; Johnston, I.D.; Kinnear, W.J. Effects of Captopril and Oxygen on Sleep Apnoea in Patients with Mild to Moderate Congestive Cardiac Failure. Heart 1995, 73, 237-241. [CrossRef]

162. Tamura, A.; Kawano, Y.; Naono, S.; Kotoku, M.; Kadota, J. Relationship between $\beta$-Blocker Treatment and the Severity of Central Sleep Apnea in Chronic Heart Failure. Chest 2007, 131, 130-135. [CrossRef]

163. Lane, T. Nocturia. Surgery 2019, 37, 388-392. [CrossRef]

164. Mcsharry, D.G.; Ryan, S.; Calverley, P.; Edwards, J.C.; Mcnicholas, W.T. Sleep Quality in Chronic Obstructive Pulmonary Disease: Sleep Quality in COPD. Respirology 2012, 17, 1119-1124. [CrossRef]

165. Valipour, A.; Lavie, P.; Lothaller, H.; Mikulic, I.; Burghuber, O.C. Sleep Profile and Symptoms of Sleep Disorders in Patients with Stable Mild to Moderate Chronic Obstructive Pulmonary Disease. Sleep Med. 2011, 12, 367-372. [CrossRef] [PubMed]

166. Jung, W.-S.; Seok, K.-J.; Ryu, J.-Y.; Lee, J.-M.; Park, J.-B.; Shin, K.; Jang, S. Risk Factors Associated with the Quality of Sleep of Patients with Chronic Obstructive Pulmonary Disease. Korean J. Fam. Pract. 2016, 6, 610-616. [CrossRef]

167. Luyster, F.S.; Shi, X.; Baniak, L.M.; Morris, J.L.; Chasens, E.R. Associations of Sleep Duration with Patient-Reported Outcomes and Health Care Use in US Adults with Asthma. Ann. Allergy Asthma Immunol. 2020, 125, 319-324. [CrossRef] [PubMed] 
168. Braido, F.; Baiardini, I.; Ghiglione, V.; Fassio, O.; Bordo, A.; Cauglia, S.; Canonica, G.W. Sleep Disturbances and Asthma Control: A Real Life Study. Asian Pac. J. Allergy Immunol. 2009, 27, 27-33.

169. Mastronarde, J.G.; Wise, R.A.; Shade, D.M.; Olopade, C.O.; Scharf, S.M.; for the American Lung Association Asthma Clinical Research Centers. Sleep Quality in Asthma: Results of a Large Prospective Clinical Trial. J. Asthma 2008, 45, 183-189. [CrossRef]

170. Lee, Y.-D.; Kim, J.-Y.; Lee, K.-H.; Kwak, Y.-J.; Lee, S.-K.; Kim, O.-S.; Song, D.-Y.; Lee, J.-H.; Baik, T.-K.; Kim, B.-J.; et al. Melatonin Attenuates Lipopolysaccharide-Induced Acute Lung Inflammation in Sleep-Deprived Mice. J. Pineal Res. 2009, 46, 53-57. [CrossRef] [PubMed]

171. Phillips, B.A.; Cooper, K.R.; Burke, T.V. The Effect of Sleep Loss on Breathing in Chronic Obstructive Pulmonary Disease. Chest 1987, 91, 29-32. [CrossRef]

172. Xie, A. Effect of Sleep on Breathing-Why Recurrent Apneas Are Only Seen during Sleep. J. Thorac. Dis. 2012, 4, 194-197. [CrossRef]

173. McNicholas, W.T.; Hansson, D.; Schiza, S.; Grote, L. Sleep in Chronic Respiratory Disease: COPD and Hypoventilation Disorders. Eur. Respir. Rev. 2019, 28, 190064. [CrossRef]

174. Budhiraja, R.; Siddiqi, T.A.; Quan, S.F. Sleep Disorders in Chronic Obstructive Pulmonary Disease: Etiology, Impact, and Management. J. Clin. Sleep Med. 2015, 11, 259-270. [CrossRef]

175. The Long-Term Oxygen Treatment Trial Research Group. A Randomized Trial of Long-Term Oxygen for COPD with Moderate Desaturation. N. Engl. J. Med. 2016, 375, 1617-1627. [CrossRef] [PubMed]

176. Moser, N.J.; Phillips, B.A.; Guthrie, G.; Barnett, G. Effects of Dexamethasone on Sleep. Pharmacol. Toxicol. 1996, 79, 100-102. [CrossRef] [PubMed]

177. Roehrs, T.; Merlotti, L.; Halpin, D.; Rosenthal, L.; Roth, T. Effects of Theophylline on Nocturnal Sleep and Daytime Sleepiness / Alertness. Chest 1995, 108, 382-387. [CrossRef] [PubMed]

178. Bercovitch, R.S.; Tsai, S.C. Respiratory Medications and Sleep. Curr. Respir. Care Rep. 2012, 1, 123-130. [CrossRef]

179. Roth, T. Hypnotic Use for Insomnia Management in Chronic Obstructive Pulmonary Disease. Sleep Med. 2009, 10, 19-25. [CrossRef]

180. Halvani, A.; Mohsenpour, F; Eshaghieh Firouz Abadi, E. Effect of Melatonin on Sleep Quality of Chronic Obstructive Pulmonary Disease (COPD) Patients. Eur. Respir. J. 2012, 40 (Suppl. S56), P3477.

181. Nunes, D.M.; Mota, R.M.S.; Machado, M.O.; Pereira, E.D.B.; de Bruin, V.M.S.; de Bruin, P.F.C. Effect of Melatonin Administration on Subjective Sleep Quality in Chronic Obstructive Pulmonary Disease. Braz. J. Med. Biol. Res. 2008, 41, 926-931. [CrossRef]

182. De Matos Cavalcante, A.G.; de Bruin, P.F.C.; de Bruin, V.M.S.; Nunes, D.M.; Pereira, E.D.B.; Cavalcante, M.M.; Andrade, G.M. Melatonin Reduces Lung Oxidative Stress in Patients with Chronic Obstructive Pulmonary Disease: A Randomized, Double-Blind, Placebo-Controlled Study: Melatonin Reduces Oxidative Stress in COPD. J. Pineal Res. 2012, 53, 238-244. [CrossRef]

183. Lavigne, G.; Zucconi, M.; Castronovo, C.; Manzini, C.; Marchettini, P.; Smirne, S. Sleep Arousal Response to Experimental Thermal Stimulation during Sleep in Human Subjects Free of Pain and Sleep Problems. Pain 2000, 84, 283-290. [CrossRef]

184. Smith, M.T.; Edwards, R.R.; McCann, U.D.; Haythornthwaite, J.A. The Effects of Sleep Deprivation on Pain Inhibition and Spontaneous Pain in Women. Sleep 2007, 30, 494-505. [CrossRef]

185. Alsaadi, S.M.; McAuley, J.H.; Hush, J.M.; Lo, S.; Lin, C.-W.C.; Williams, C.M.; Maher, C.G. Poor Sleep Quality Is Strongly Associated With Subsequent Pain Intensity in Patients with Acute Low Back Pain: Sleep Quality and Pain Intensity. Arthritis Rheumatol. 2014, 66, 1388-1394. [CrossRef]

186. Affleck, G.; Urrows, S.; Tennen, H.; Higgins, P.; Abeles, M. Sequential Daily Relations of Sleep, Pain Intensity, and Attention to Pain among Women with Fibromyalgia. Pain 1996, 68, 363-368. [CrossRef]

187. Woo, A.; Ratnayake, G. Sleep and Pain Management: A Review. Pain Manag. 2020, 10, 261-273. [CrossRef] [PubMed]

188. Swift, A. Evidence That Active Pain Treatment Improves Sleep Quality and Quantity in People with Depression and Dementia. Evid. Based Nurs. 2019, 22, 49. [CrossRef] [PubMed]

189. Koffel, E.; McCurry, S.M.; Smith, M.T.; Vitiello, M.V. Improving Pain and Sleep in Middle-Aged and Older Adults: The Promise of Behavioral Sleep Interventions. Pain 2019, 160, 529-534. [CrossRef] [PubMed]

190. Jansson, C.; Nordenstedt, H.; Wallander, M.; Johansson, S.; Johnsen, R.; Hveem, K.; Lagergren, J. A Population-Based Study Showing an Association between Gastroesophageal Reflux Disease and Sleep Problems. Clin. Gastroenterol. Hepatol. 2009, 7 , 960-965. [CrossRef] [PubMed]

191. Shaker, R.; Castell, D.O.; Schoenfeld, P.S.; Spechler, S.J. Nighttime Heartburn Is an Under-Appreciated Clinical Problem That Impacts Sleep and Daytime Function: The Results of a Gallup Survey Conducted on Behalf of the American Gastroenterological Association. Am. J. Gastroenterol. 2003, 98, 1487-1493. [CrossRef] [PubMed]

192. Jung, H.; Choung, R.S.; Talley, N.J. Gastroesophageal Reflux Disease and Sleep Disorders: Evidence for a Causal Link and Therapeutic Implications. J. Neurogastroenterol. Motil. 2010, 16, 22-29. [CrossRef] [PubMed]

193. Fujiwara, Y.; Arakawa, T.; Fass, R. Gastroesophageal Reflux Disease and Sleep Disturbances. J. Gastroenterol. 2012, 47, 760-769. [CrossRef]

194. Johnson, D.A.; Orr, W.C.; Crawley, J.A.; Traxler, B.; McCullough, J.; Brown, K.A.; Roth, T. Effect of Esomeprazole on Nighttime Heartburn and Sleep Quality in Patients with GERD: A Randomized, Placebo-Controlled Trial. Am. J. Gastroenterol. 2005, 100, 1914-1922. [CrossRef]

195. Ancoli-Israel, S.; Bliwise, D.L.; Nørgaard, J.P. The Effect of Nocturia on Sleep. Sleep Med. Rev. 2011, 15, 91-97. [CrossRef] 
196. Cai, T.; Gardener, N.; Abraham, L.; Boddi, V.; Abrams, P.; Bartoletti, R. Impact of Surgical Treatment on Nocturia in Men with Benign Prostatic Obstruction. BJU Int. 2006, 98, 799-805. [CrossRef]

197. Yu, H.-J.; Chen, F.-Y.; Huang, P.-C.; Chen, T.H.-H.; Chie, W.-C.; Liu, C.-Y. Impact of Nocturia on Symptom-Specific Quality of Life among Community-Dwelling Adults Aged 40 Years and Older. Urology 2006, 67, 713-718. [CrossRef]

198. Bliwise, D.L.; Dijk, D.-J.; Juul, K.V. Nocturia Is Associated with Loss of Deep Sleep Independently from Sleep Apnea: Sleep Apnea Is a Well-Acknowledged Reversible. Neurourol. Urodynam. 2015, 34, 392. [CrossRef] [PubMed]

199. Roth, T. Slow Wave Sleep: Does It Matter? J. Clin. Sleep Med. 2009, 5 (Suppl. S2), S4-S5. [CrossRef] [PubMed]

200. Bliwise, D.L.; Foley, D.J.; Vitiello, M.V.; Ansari, F.P.; Ancoli-Israel, S.; Walsh, J.K. Nocturia and Disturbed Sleep in the Elderly. Sleep Med. 2009, 10, 540-548. [CrossRef] [PubMed]

201. Chung, J.H.; Moon, H.S.; Park, S.Y.; Kim, K.R.; Cho, S.H.; Kim, Y.T. Effect of Nocturnal Hypoxia on Nocturia in Patients with Obstructive Sleep Apnea. Int. Neurourol. J. 2019, 23, 161-168. [CrossRef] [PubMed]

202. Kabadi, U.M. SGLT2 Inhibitors: Far Too Many Cautions and Alerts and Limited Efficacy. JDMDC 2016, 3. [CrossRef]

203. Hall, S.A.; Chiu, G.R.; Kaufman, D.W.; Wittert, G.A.; Link, C.L.; McKinlay, J.B. Commonly Used Antihypertensives and Lower Urinary Tract Symptoms: Results from the Boston Area Community Health (BACH) Survey: Antihypertensives and Luts. BJU Int. 2012, 109, 1676-1684. [CrossRef]

204. Vaughan, C.P.; Bliwise, D.L. Sleep and Nocturia in Older Adults. Sleep Med. Clin. 2018, 13, 107-116. [CrossRef]

205. Everaert, K.; Hervé, F.; Bosch, R.; Dmochowski, R.; Drake, M.; Hashim, H.; Chapple, C.; Van Kerrebroeck, P.; Mourad, S.; Abrams, P.; et al. International Continence Society Consensus on the Diagnosis and Treatment of Nocturia. Neurourol. Urodyn. 2019, 38, 478-498. [CrossRef] [PubMed]

206. Bliwise, D.L.; Holm-Larsen, T.; Goble, S.; Nørgaard, J.P. Short Time to First Void Is Associated with Lower Whole-Night Sleep Quality in Nocturia Patients. J. Clin. Sleep Med. 2015, 11, 53-55. [CrossRef] [PubMed]

207. Bliwise, D.L.; Holm-Larsen, T.; Goble, S.; Juul, K.V.; van der Meulen, E.; Nørgaard, J.P. Delay of First Voiding Episode Is Associated with Longer Reported Sleep Duration. Sleep Health 2015, 1, 211-213. [CrossRef] [PubMed]

208. Musiek, E.S.; Holtzman, D.M. Mechanisms Linking Circadian Clocks, Sleep, and Neurodegeneration. Science 2016, 354, 1004-1008. [CrossRef]

209. Videnovic, A.; Abbott, S. Chronic Sleep Disturbance and Neural Injury: Links to Neurodegenerative Disease. NSS 2016, 8 , 55-61. [CrossRef]

210. Iranzo, A. Parkinson Disease and Sleep: Sleep-Wake Changes in the Premotor Stage of Parkinson Disease; Impaired Olfaction and Other Prodromal Features. Curr. Neurol. Neurosci. Rep. 2013, 13, 373. [CrossRef]

211. Postuma, R.B.; Lang, A.E.; Gagnon, J.F.; Pelletier, A.; Montplaisir, J.Y. How Does Parkinsonism Start? Prodromal Parkinsonism Motor Changes in Idiopathic REM Sleep Behaviour Disorder. Brain 2012, 135, 1860-1870. [CrossRef]

212. Iranzo, A. Sleep-Wake Changes in the Premotor Stage of Parkinson Disease. J. Neurol. Sci. 2011, 310, 283-285. [CrossRef]

213. Mao, C.; Yang, Y.; Chen, J.; Wang, F.; Chen, J.; Zhang, J.; Zhang, H.; Zhuang, S.; Xiong, Y.; Gu, C.; et al. Poor Nighttime Sleep Is Positively Associated with Dyskinesia in Parkinson's Disease Patients. Parkinsonism Relat. Disord. 2018, 48, 68-73. [CrossRef]

214. Van Gilst, M.M.; Bloem, B.R.; Overeem, S. “Sleep Benefit” in Parkinson's Disease: A Systematic Review. Parkinsonism Relat. Disord. 2013, 19, 654-659. [CrossRef]

215. Winge, K.; Skau, A.-M.; Stimpel, H.; Nielsen, K.K.; Werdelin, L. Prevalence of Bladder Dysfunction in Parkinsons Disease. Neurourol. Urodyn. 2006, 25, 116-122. [CrossRef] [PubMed]

216. Vaughan, C.P.; Juncos, J.L.; Trotti, L.M.; Johnson, T.M.; Bliwise, D.L. Nocturia and Overnight Polysomnography in Parkinson Disease: Nocturia and Polysomnography in Parkinson Disease. Neurourol. Urodynam. 2013, 32, 1080-1085. [CrossRef] [PubMed]

217. Van Hilten, B. Sleep Disruption in Parkinson's Disease: Assessment by Continuous Activity Monitoring. Arch. Neurol. 1994, 51, 922. [CrossRef] [PubMed]

218. Starkstein, S.E.; Preziosi, T.J.; Robinson, R.G. Sleep Disorders, Pain, and Depression in Parkinson's Disease. Eur. Neurol. 1991, 31, 352-355. [CrossRef] [PubMed]

219. De Cock, V.C.; Vidailhet, M.; Arnulf, I. Sleep Disturbances in Patients with Parkinsonism. Nat. Rev. Neurol. 2008, 4, 254-266. [CrossRef]

220. Berg, D.; Postuma, R.B.; Adler, C.H.; Bloem, B.R.; Chan, P.; Dubois, B.; Gasser, T.; Goetz, C.G.; Halliday, G.; Joseph, L.; et al. MDS Research Criteria for Prodromal Parkinson's Disease: MDS Criteria for Prodromal PD. Mov. Disord. 2015, 30, $1600-1611$. [CrossRef] [PubMed]

221. Garcia-Borreguero, D.; Larrosa, O.; Bravo, M. Parkinson's Disease and Sleep. Sleep Med. Rev. 2003, 7, 115-129. [CrossRef]

222. Wailke, S.; Herzog, J.; Witt, K.; Deuschl, G.; Volkmann, J. Effect of Controlled-Release Levodopa on the Microstructure of Sleep in Parkinson's Disease: L-Dopa Effect on PD Sleep. Eur. J. Neurol. 2011, 18, 590-596. [CrossRef]

223. Brunner, H.; Wetter, T.C.; Hogl, B.; Yassouridis, A.; Trenkwalder, C.; Friess, E. Microstructure of the Non-Rapid Eye Movement Sleep Electroencephalogram in Patients with Newly Diagnosed Parkinson's Disease: Effects of Dopaminergic Treatment. Mov. Disord. 2002, 17, 928-933. [CrossRef] [PubMed]

224. Stocchi, F.; Barbato, L.; Nordera, G.; Berardelli, A.; Ruggieri, S. Sleep Disorders in Parkinson's Disease. J. Neurol. 1998, 245 (Suppl. S1), S15-S18. [CrossRef]

225. Loddo, G.; Calandra-Buonaura, G.; Sambati, L.; Giannini, G.; Cecere, A.; Cortelli, P.; Provini, F. The Treatment of Sleep Disorders in Parkinson's Disease: From Research to Clinical Practice. Front. Neurol. 2017, 8. [CrossRef] 
226. Pierantozzi, M.; Placidi, F.; Liguori, C.; Albanese, M.; Imbriani, P.; Marciani, M.G.; Mercuri, N.B.; Stanzione, P.; Stefani, A. Rotigotine May Improve Sleep Architecture in Parkinson's Disease: A Double-Blind, Randomized, Placebo-Controlled Polysomnographic Study. Sleep Med. 2016, 21, 140-144. [CrossRef] [PubMed]

227. Calandra-Buonaura, G.; Guaraldi, P.; Doria, A.; Zanigni, S.; Nassetti, S.; Favoni, V.; Cevoli, S.; Provini, F.; Cortelli, P. Rotigotine Objectively Improves Sleep in Parkinson's Disease: An Open-Label Pilot Study with Actigraphic Recording. Parkinson's Dis. 2016, 2016, 1-5. [CrossRef] [PubMed]

228. Melone, M.A.; Schettino, C.; Dato, C.; Capaldo, G.; Sampaolo, S.; Di Iorio, G. Rasagiline for Sleep Disorders in Patients with Parkinson\&rsquo's Disease: A Prospective Observational Study. NDT 2016, 12, 2497-2502. [CrossRef]

229. Schroeck, J.L.; Ford, J.; Conway, E.L.; Kurtzhalts, K.E.; Gee, M.E.; Vollmer, K.A.; Mergenhagen, K.A. Review of Safety and Efficacy of Sleep Medicines in Older Adults. Clin. Ther. 2016, 38, 2340-2372. [CrossRef]

230. Bordet, R.; Devos, D.; Brique, S.; Touitou, Y.; Guieu, J.D.; Libersa, C.; Destée, A. Study of Circadian Melatonin Secretion Pattern at Different Stages of Parkinson's Disease. Clin. Neuropharmacol. 2003, 26, 65-72. [CrossRef]

231. Dowling, G.A.; Mastick, J.; Colling, E.; Carter, J.H.; Singer, C.M.; Aminoff, M.J. Melatonin for Sleep Disturbances in Parkinson's Disease. Sleep Med. 2005, 6, 459-466. [CrossRef]

232. Medeiros, C.A.M.; Carvalhedo de Bruin, P.F.; Lopes, L.A.; Magalhães, M.C.; de Lourdes Seabra, M.; Sales de Bruin, V.M. Effect of Exogenous Melatonin on Sleep and Motor Dysfunction in Parkinson's Disease: A Randomized, Double Blind, Placebo-Controlled Study. J. Neurol. 2007, 254, 459-464. [CrossRef]

233. Lucey, B.P. It's Complicated: The Relationship between Sleep and Alzheimer's Disease in Humans. Neurobiol. Dis. 2020, 144, 105031. [CrossRef] [PubMed]

234. Guarnieri, B.; Sorbi, S. Sleep and Cognitive Decline: A Strong Bidirectional Relationship. It Is Time for Specific Recommendations on Routine Assessment and the Management of Sleep Disorders in Patients with Mild Cognitive Impairment and Dementia. Eur. Neurol. 2015, 74, 43-48. [CrossRef]

235. Lloret, M.-A.; Cervera-Ferri, A.; Nepomuceno, M.; Monllor, P.; Esteve, D.; Lloret, A. Is Sleep Disruption a Cause or Consequence of Alzheimer's Disease? Reviewing Its Possible Role as a Biomarker. IJMS 2020, 21, 1168. [CrossRef]

236. Bubu, O.M.; Brannick, M.; Mortimer, J.; Umasabor-Bubu, O.; Sebastião, Y.V.; Wen, Y.; Schwartz, S.; Borenstein, A.R.; Wu, Y.; Morgan, D.; et al. Sleep, Cognitive Impairment, and Alzheimer's Disease: A Systematic Review and Meta-Analysis. Sleep 2017, 40. [CrossRef] [PubMed]

237. McCurry, S.M.; Ancoli-Israel, S. Sleep Dysfunction in Alzheimer's Disease and Other Dementias. Curr. Treat. Options Neurol. 2003, 5, 261-272. [CrossRef]

238. Brzecka, A.; Leszek, J.; Ashraf, G.M.; Ejma, M.; Ávila-Rodriguez, M.F.; Yarla, N.S.; Tarasov, V.V.; Chubarev, V.N.; Samsonova, A.N.; Barreto, G.E.; et al. Sleep Disorders Associated With Alzheimer's Disease: A Perspective. Front. Neurosci. 2018, 12, 330. [CrossRef]

239. Chwiszczuk, L.; Breitve, M.; Hynninen, M.; Gjerstad, M.D.; Aarsland, D.; Rongve, A. Higher Frequency and Complexity of Sleep Disturbances in Dementia with Lewy Bodies as Compared to Alzheimer's Disease. Neurodegener. Dis. 2016, 16, 152-160. [CrossRef] [PubMed]

240. Pollak, C.P.; Perlick, D.; Linsner, J.P.; Wenston, J.; Hsieh, F. Sleep Problems in the Community Elderly as Predictors of Death and Nursing Home Placement. J. Community Health 1990, 15, 123-135. [CrossRef] [PubMed]

241. McCurry, S.M.; Logsdon, R.G.; Teri, L.; Gibbons, L.E.; Kukull, W.A.; Bowen, J.D.; McCormick, W.C.; Larson, E.B. Characteristics of Sleep Disturbance in Community-Dwelling Alzheimer's Disease Patients. J. Geriatr. Psychiatry Neurol. 1999, 12, 53-59. [CrossRef] [PubMed]

242. Gehrman, P.; Gooneratne, N.S.; Brewster, G.S.; Richards, K.C.; Karlawish, J. Impact of Alzheimer Disease Patients' Sleep Disturbances on Their Caregivers. Geriatr. Nurs. 2018, 39, 60-65. [CrossRef]

243. Okuda, S.; Tetsuka, J.; Takahashi, K.; Toda, Y.; Kubo, T.; Tokita, S. Association between Sleep Disturbance in Alzheimer's Disease Patients and Burden on and Health Status of Their Caregivers. J. Neurol. 2019, 266, 1490-1500. [CrossRef]

244. McCleery, J.; Cohen, D.A.; Sharpley, A.L. Pharmacotherapies for Sleep Disturbances in Alzheimer's Disease. In Cochrane Database of Systematic Reviews; The Cochrane Collaboration; John Wiley \& Sons, Ltd.: Chichester, UK, 2014. [CrossRef]

245. Xu, J.; Wang, L.-L.; Dammer, E.B.; Li, C.-B.; Xu, G.; Chen, S.-D.; Wang, G. Melatonin for Sleep Disorders and Cognition in Dementia: A Meta-Analysis of Randomized Controlled Trials. Am. J. Alzheimers Dis. Other Demen. 2015, 30, 439-447. [CrossRef]

246. De Jonghe, A.; Korevaar, J.C.; van Munster, B.C.; de Rooij, S.E. Effectiveness of Melatonin Treatment on Circadian Rhythm Disturbances in Dementia. Are There Implications for Delirium? A Systematic Review. Int. J. Geriat. Psychiatry 2010, 25, 1201-1208. [CrossRef] [PubMed]

247. Bessey, L.J.; Walaszek, A. Management of Behavioral and Psychological Symptoms of Dementia. Curr. Psychiatry Rep. 2019, 21, 66. [CrossRef]

248. O'Caoimh, R.; Mannion, H.; Sezgin, D.; O’Donovan, M.R.; Liew, A.; Molloy, D.W. Non-Pharmacological Treatments for Sleep Disturbance in Mild Cognitive Impairment and Dementia: A Systematic Review and Meta-Analysis. Maturitas 2019, 127, 82-94. [CrossRef] [PubMed]

249. Cassidy-Eagle, E.; Siebern, A.; Unti, L.; Glassman, J.; O’Hara, R. Neuropsychological Functioning in Older Adults with Mild Cognitive Impairment and Insomnia Randomized to CBT-I or Control Group. Clin. Gerontol. 2018, 41, 136-144. [CrossRef] [PubMed] 
250. Kyle, S.D.; Hurry, M.E.D.; Emsley, R.; Marsden, A.; Omlin, X.; Juss, A.; Spiegelhalder, K.; Bisdounis, L.; Luik, A.I.; Espie, C.A.; et al. The Effects of Digital Cognitive Behavioral Therapy for Insomnia on Cognitive Function: A Randomized Controlled Trial. Sleep 2020, 43, zsaa034. [CrossRef] [PubMed]

251. Pagel, J.F. Medications and Their Effects on Sleep. Prim. Care Clin. Off. Pract. 2005, 32, 491-509. [CrossRef]

252. Chang, C.-B.; Chen, J.-H.; Wen, C.-J.; Kuo, H.-K.; Lu, I.-S.; Chiu, L.-S.; Wu, S.-C.; Chan, D.-C.D. Potentially Inappropriate Medications in Geriatric Outpatients with Polypharmacy: Application of Six Sets of Published Explicit Criteria: Potentially Inappropriate Medications in Geriatric Outpatients. Br. J. Clin. Pharmacol. 2011, 72, 482-489. [CrossRef]

253. Al Odhayani, A.; Tourkmani, A.; Alshehri, M.; Alqahtani, H.; Mishriky, A. Potentially Inappropriate Medications Prescribed for Elderly Patients through Family Physicians. Saudi J. Biol. Sci. 2017, 24, 200-207. [CrossRef] [PubMed]

254. Alturki, A.; Alaama, T.; Alomran, Y.; Al-Jedai, A.; Almudaiheem, H.; Watfa, G. Potentially Inappropriate Medications in Older Patients Based on Beers Criteria: A Cross-Sectional Study of a Family Medicine Practice in Saudi Arabia. BJGP Open 2020, 4, bjgpopen20X101009. [CrossRef]

255. Kumar, S.; Wong, P.S.; Hasan, S.S.; Kairuz, T. The Relationship between Sleep Quality, Inappropriate Medication Use and Frailty among Older Adults in Aged Care Homes in Malaysia. PLoS ONE 2019, 14, e0224122. [CrossRef]

256. Garfinkel, D. Poly-de-Prescribing to Treat Polypharmacy: Efficacy and Safety. Ther. Adv. Drug Saf. 2018, 9, 25-43. [CrossRef] [PubMed]

257. Vieira, E.R.; Freund-Heritage, R.; da Costa, B.R. Risk Factors for Geriatric Patient Falls in Rehabilitation Hospital Settings: A Systematic Review. Clin. Rehabil. 2011, 25, 788-799. [CrossRef]

258. Berková, M.; Berka, Z. Falls: A Significant Cause of Morbidity and Mortality in Elderly People. Vnitr. Lek. 2018, 64, 1076-1083.

259. Stone, K.L.; Ensrud, K.E.; Ancoli-Israel, S. Sleep, Insomnia and Falls in Elderly Patients. Sleep Med. 2008, 9, S18-S22. [CrossRef]

260. Kaushik, S.; Wang, J.J.; Mitchell, P. Sleep Apnea and Falls in Older People: Letters to the Editor. J. Am. Geriatr. Soc. 2007, 55, 1149-1150. [CrossRef] [PubMed]

261. Kuo, H.-K.; Yang, C.C.H.; Yu, Y.-H.; Tsai, K.-T.; Chen, C.-Y. Gender-Specific Association between Self-Reported Sleep Duration and Falls in High-Functioning Older Adults. J. Gerontol. Ser. A 2010, 65A, 190-196. [CrossRef] [PubMed]

262. Stone, K.L.; Blackwell, T.L.; Ancoli-Israel, S.; Cauley, J.A.; Redline, S.; Marshall, L.M.; Ensrud, K.E.; for the Osteoporotic Fractures in Men Study Group. Sleep Disturbances and Risk of Falls in Older Community-Dwelling Men: The Outcomes of Sleep Disorders in Older Men (MrOS Sleep) Study. J. Am. Geriatr. Soc. 2014, 62, 299-305. [CrossRef]

263. Suzuki, T.; Yoshida, H.; Hashimoto, T.; Yoshimura, N.; Fujiwara, S.; Fukunaga, M.; Nakamura, T.; Yoh, K.; Inoue, T.; Hosoi, T.; et al. Case-Control Study of Risk Factors for Hip Fractures in the Japanese Elderly by a Mediterranean Osteoporosis Study (MEDOS) Questionnaire. Bone 1997, 21, 461-467. [CrossRef]

264. Noh, J.-W.; Kim, K.-B.; Lee, J.H.; Lee, Y.; Lee, B.-H.; Kwon, Y.D. Association between Sleep Duration and Injury from Falling among Older Adults: A Cross-Sectional Analysis of Korean Community Health Survey Data. Yonsei Med. J. 2017, $58,1222$. [CrossRef] [PubMed]

265. Barker, A.; Cameron, P.; Flicker, L.; Arendts, G.; Brand, C.; Etherton-Beer, C.; Forbes, A.; Haines, T.; Hill, A.-M.; Hunter, P.; et al. Evaluation of Respond, a Patient-Centred Program to Prevent Falls in Older People Presenting to the Emergency Department with a Fall: A Randomised Controlled Trial. PLoS Med. 2019, 16, e1002807. [CrossRef]

266. Aeschbach, D.; Santhi, N. Attention and Memory Changes. In Encyclopedia of Sleep; Elsevier: Amsterdam, The Netherlands, 2013; pp. 217-224. [CrossRef]

267. Hill, E.L.; Cumming, R.G.; Lewis, R.; Carrington, S.; Couteur, D.G.L. Sleep Disturbances and Falls in Older People. J. Gerontol. Ser. A 2007, 62, 62-66. [CrossRef] [PubMed]

268. Liu, Y.; Chan, J.S.Y.; Yan, J.H. Neuropsychological Mechanisms of Falls in Older Adults. Front. Aging Neurosci. $2014,6$. [CrossRef] [PubMed]

269. Kim, S.Y.; Bang, W.; Kim, M.-S.; Park, B.; Kim, J.-H.; Choi, H.G. Nocturia Is Associated with Slipping and Falling. PLoS ONE 2017, 12, e0169690. [CrossRef] [PubMed]

270. Khot, S.P.; Morgenstern, L.B. Sleep and Stroke. Stroke 2019, 50, 1612-1617. [CrossRef] [PubMed]

271. Fiorentino, L.; Ancoli-Israel, S. Sleep Dysfunction in Patients with Cancer. Curr. Treat. Options Neurol. 2007, 9, 337-346. [CrossRef]

272. Gangwisch, J.E. A Review of Evidence for the Link between Sleep Duration and Hypertension. Am. J. Hypertens. 2014, 27, 1235-1242. [CrossRef] [PubMed]

273. Ogilvie, R.P.; Patel, S.R. The Epidemiology of Sleep and Diabetes. Curr. Diab. Rep. 2018, 18, 82. [CrossRef] [PubMed]

274. Zhou, Q.; Zhang, M.; Hu, D. Dose-Response Association between Sleep Duration and Obesity Risk: A Systematic Review and Meta-Analysis of Prospective Cohort Studies. Sleep Breath 2019, 23, 1035-1045. [CrossRef]

275. Hanly, P. Sleep Disorders and End-Stage Renal Disease. Curr. Opin. Pulm. Med. 2008, 14, 543-550. [CrossRef]

276. Buysse, D.J.; Reynolds, C.F.; Monk, T.H.; Berman, S.R.; Kupfer, D.J. The Pittsburgh Sleep Quality Index: A New Instrument for Psychiatric Practice and Research. Psychiatry Res. 1989, 28, 193-213. [CrossRef]

277. Beaudreau, S.A.; Spira, A.P.; Stewart, A.; Kezirian, E.J.; Lui, L.-Y.; Ensrud, K.; Redline, S.; Ancoli-Israel, S.; Stone, K.L. Validation of the Pittsburgh Sleep Quality Index and the Epworth Sleepiness Scale in Older Black and White Women. Sleep Med. 2012, 13, 36-42. [CrossRef] [PubMed] 
278. Spira, A.P.; Beaudreau, S.A.; Stone, K.L.; Kezirian, E.J.; Lui, L.-Y.; Redline, S.; Ancoli-Israel, S.; Ensrud, K.; Stewart, A.; for the Osteoporotic Fractures in Men Study. Reliability and Validity of the Pittsburgh Sleep Quality Index and the Epworth Sleepiness Scale in Older Men. J. Gerontol. Ser. A 2012, 67A, 433-439. [CrossRef]

279. Frohnhofen, H.; Popp, R.; Stieglitz, S.; Netzer, N.; Danker-Hopfe, H. Assessment of Sleep and Sleep Disorders in Geriatric Patients. Z Gerontol. Geriat. 2020, 53, 100-104. [CrossRef]

280. Johns, M.W. A New Method for Measuring Daytime Sleepiness: The Epworth Sleepiness Scale. Sleep 1991, 14, 540-545. [CrossRef] [PubMed]

281. Frohnhofen, H.; Popp, R.; Willmann, V.; Heuer, H.C.; Firat, A. Feasibility of the Epworth Sleepiness Scale in a Sample of Geriatric In-Hospital Patients. J. Physiol. Pharm. 2009, 60 (Suppl. 5), 45-49.

282. Bastien, C. Validation of the Insomnia Severity Index as an Outcome Measure for Insomnia Research. Sleep Med. 2001, 2, 297-307. [CrossRef]

283. Sierra, J.C.; Guillén-Serrano, V.; Santos-Iglesias, P. Insomnia Severity Index: Some indicators about its reliability and validity on an older adults sample. Rev. Neurol. 2008, 47, 566-570.

284. Yu, D.S.F. Insomnia Severity Index: Psychometric Properties with Chinese Community-Dwelling Older People: Insomnia Severity Index. J. Adv. Nurs. 2010, 66, 2350-2359. [CrossRef]

285. Full, K.M.; Malhotra, A.; Crist, K.; Moran, K.; Kerr, J. Assessing Psychometric Properties of the Promis Sleep Disturbance Scale in Older Adults in Independent-Living and Continuing Care Retirement Communities. Sleep Health 2019, 5, 18-22. [CrossRef]

286. Buysse, D.J.; Yu, L.; Moul, D.E.; Germain, A.; Stover, A.; Dodds, N.E.; Johnston, K.L.; Shablesky-Cade, M.A.; Pilkonis, P.A. Development and Validation of Patient-Reported Outcome Measures for Sleep Disturbance and Sleep-Related Impairments. Sleep 2010, 33, 781-792. [CrossRef] [PubMed]

287. Frohnhofen, H.; Fulda, S.; Frohnhofen, K.; Popp, R. Validation of the Essener Questionnaire of Age and Sleepiness in the Elderly Using Pupillometry. In Respiratory Regulation-Clinical Advances; Pokorski, M., Ed.; Advances in Experimental Medicine and Biology; Springer: Dordrecht, The Netherlands, 2013; Volume 755, pp. 125-132. [CrossRef]

288. Netzer, N.C.; Stoohs, R.A.; Netzer, C.M.; Clark, K.; Strohl, K.P. Using the Berlin Questionnaire To Identify Patients at Risk for the Sleep Apnea Syndrome. Ann. Intern. Med. 1999, 131, 485. [CrossRef]

289. Sforza, E.; Chouchou, F.; Pichot, V.; Herrmann, F.; Barthélémy, J.C.; Roche, F. Is the Berlin Questionnaire a Useful Tool to Diagnose Obstructive Sleep Apnea in the Elderly? Sleep Med. 2011, 12, 142-146. [CrossRef] [PubMed]

290. Pallesen, S.; Bjorvatn, B.; Nordhus, I.H.; Sivertsen, B.; Hjørnevik, M.; Morin, C.M. A New Scale for Measuring Insomnia: The Bergen Insomnia Scale. Percept. Mot. Ski. 2008, 107, 691-706. [CrossRef]

291. Martins, E.F.; Martinez, D.; Cortes, A.L.; Nascimento, N.; Brendler, J. Exploring the Stop-Bang Questionnaire for Obstructive Sleep Apnea Screening in Seniors. J. Clin. Sleep Med. 2020, 16, 199-206. [CrossRef]

292. Flemons, W.W.; Whitelaw, W.A.; Brant, R.; Remmers, J.E. Likelihood Ratios for a Sleep Apnea Clinical Prediction Rule. Am. J. Respir. Crit. Care Med. 1994, 150, 1279-1285. [CrossRef]

293. Henrique da Costa, C.; Costa Faria, A.; Rufino, R. Sleep Apnea Clinical Score, Berlin Questionnaire, or Epworth Sleepiness Scale: Which Is the Best Obstructive Sleep Apnea Predictor in Patients with COPD? IJGM 2015, 8, 275-281. [CrossRef] [PubMed] 